\title{
Austenite Formation from Martensite in a 13Cr6Ni2Mo Supermartensitic Stainless Steel
}

\begin{abstract}
A. BOJACK, L. ZHAO, P.F. MORRIS, and J. SIETSMA
The influence of austenitization treatment of a $13 \mathrm{Cr} 6 \mathrm{Ni} 2 \mathrm{Mo}$ supermartensitic stainless steel (X2CrNiMoV13-5-2) on austenite formation during reheating and on the fraction of austenite retained after tempering treatment is measured and analyzed. The results show the formation of austenite in two stages. This is probably due to inhomogeneous distribution of the austenite-stabilizing elements $\mathrm{Ni}$ and $\mathrm{Mn}$, resulting from their slow diffusion from martensite into austenite and carbide and nitride dissolution during the second, higher temperature, stage. A better homogenization of the material causes an increase in the transformation temperatures for the martensite-to-austenite transformation and a lower retained austenite fraction with less variability after tempering. Furthermore, the martensite-to-austenite transformation was found to be incomplete at the target temperature of $1223 \mathrm{~K}\left(950^{\circ} \mathrm{C}\right)$, which is influenced by the previous austenitization treatment and the heating rate. The activation energy for martensite-to-austenite transformation was determined by a modified Kissinger equation to be approximately 400 and $500 \mathrm{~kJ} / \mathrm{mol}$ for the first and the second stages of transformation, respectively. Both values are much higher than the activation energy found during isothermal treatment in a previous study and are believed to be effective activation energies comprising the activation energies of both mechanisms involved, i.e., nucleation and growth.
\end{abstract}

DOI: $10.1007 / \mathrm{s} 11661-016-3404-\mathrm{z}$

(C) The Author(s) 2016. This article is published with open access at Springerlink.com

\section{INTRODUCTION}

SUPERMARTENSITIC stainless steels (SMSS) have been developed from soft-martensitic stainless steels, containing a much lower level of the interstitials $\mathrm{C}$ and $\mathrm{N}^{[1]}$ and possessing an outstanding combination of properties, i.e., high strength, good toughness, good corrosion resistance, and reasonable weldability. ${ }^{[1-4]}$ Due to the increasing need for a more cost-effective use of materials, they have been further developed in the past 20 years and are increasingly being applied in the offshore oil and gas industry to replace highly alloyed alternatives. $^{[2,3]}$ The properties of SMSS, particularly the yield stress, are strongly dependent on the fraction of retained austenite. ${ }^{[5]}$ This can be controlled by the heat treatment, which consists of an austenitization treatment followed by tempering, usually double tempering, just above the $A_{\mathrm{c} 1}$ temperature. The resulting microstructure after double tempering consists of

A. BOJACK, Ph.D Researcher, is with the Department of Materials Science and Engineering, Delft University of Technology, Mekelweg 2, $2628 \mathrm{CD}$ Delft, The Netherlands, and also with the Materials innovation institute (M2i), Mekelweg 2, 2628 CD Delft, The Netherlands. L. ZHAO, Research Fellow, formerly with the Materials innovation institute (M2i), and with the Department of Materials Science and Engineering, Delft University of Technology, is now with VDL Weweler B.V., Ecofactorij 10, 7325 WC Apeldoorn, The Netherlands. P.F. MORRIS, was formerly Research Fellow at Tata Steel, Swinden Technology Centre, Moorgate, Rotherham, South Yorkshire S60 3AR, U.K. J. SIETSMA, Professor, is with the Department of Materials Science and Engineering, Delft University of Technology. Contact e-mail: J.Sietsma@tudelft.nl

Manuscript submitted January 19, 2015.

Article published online February 26, 2016 low-carbon martensite and finely dispersed austenite that is retained at room temperature. ${ }^{[5,6]}$ It is well known that the stability of austenite depends on the concentrations of austenite-stabilizing elements in the phase, ${ }^{[5-8]}$ which are mainly $\mathrm{Ni}^{[9-12]}$ and $\mathrm{Mn}^{[13]}$ in SMSS. This is critically dependent on the microstructural evolution during the annealing steps.

It was found from austenitization experiments with a 13Cr6Ni2Mo SMSS, presented in a previous study, ${ }^{[14]}$ that the formation of austenite from martensite takes place in two stages during heating. However, these experiments have been carried out with as-received, double-tempered material, containing about $21 \mathrm{vol}$ pct retained austenite. It was argued that the reason for the two-stage transformation could be the partitioning of $\mathrm{Ni}$ to austenite, where the martensite with a lower $\mathrm{Ni}$ concentration has a higher $A_{\mathrm{c} 1}$ temperature and therefore transforms to austenite at a higher temperature. These two stages were found by dilatometry to be distinct, even though most of the austenite-stabilizing elements that would have caused this effect are already dissolved in austenite. As a consequence, the differences in $\mathrm{Ni}$ concentration were considered to be the most likely cause of the two-stage austenite formation. Since for SMSS the heat treatment is crucial for obtaining the desired properties of high strength and good toughness, control of the austenitization step is important, as it determines the levels of alloy in solution and their distribution prior to subsequent tempering.

The austenitization treatment of low-carbon martensitic stainless steels and SMSS is carried out above the $A_{\mathrm{c} 3}$ temperature, usually between $1223 \mathrm{~K}$ and $1373 \mathrm{~K}$ 
$\left(950{ }^{\circ} \mathrm{C}\right.$ and $\left.1100{ }^{\circ} \mathrm{C}\right) .^{[4,6,12,13,15-19]}$ This is to obtain an almost fully martensitic microstructure after cooling to ambient temperature by avoiding formation of delta-ferrite, which can have detrimental effects on the properties. It was observed for different SMSS grades that the prior austenite grain size, together with the width of the martensite laths, was increasing with increasing austenitization temperature, ${ }^{[20-22]}$ whereas the hardness was decreasing. ${ }^{[21,22]}$ Liu et al. ${ }^{[20]}$ found for SMSS (in wt pet: $0.02 \mathrm{C}-12 \mathrm{Cr}-5 \mathrm{Ni}-2 \mathrm{Mo}-0.4 \mathrm{Mn}-0.2 \mathrm{Si}$ ) the grain size of the original austenite increases with increasing austenitization temperature from $1173 \mathrm{~K}$ to $1373 \mathrm{~K}\left(900{ }^{\circ} \mathrm{C}\right.$ to $1100{ }^{\circ} \mathrm{C}$ ). Moreover, they also observed that the tensile strength after tempering decreases with increasing previous austenitization temperature and that the elongation increases for austenitization up to $1323 \mathrm{~K}$ $\left(1050^{\circ} \mathrm{C}\right)$.

So far, only a limited number of studies giving a direct comparison of the influence of the austenitization treatment of SMSS on the austenite formation during reheating and on the austenite fraction obtained after tempering have been carried out. This paper focuses on the austenite formation in $13 \mathrm{Cr} 6 \mathrm{Ni} 2 \mathrm{Mo}$ SMSS, previously austenitized at different temperatures and times, during reheating at different rates and measured using dilatometry. Furthermore, the influence of the austenitization treatment on the retained austenite fraction after tempering at temperatures between $888 \mathrm{~K}$ and $928 \mathrm{~K}\left(615^{\circ} \mathrm{C}\right.$ and $\left.655^{\circ} \mathrm{C}\right)$ was analyzed using a Vibrating Sample Magnetometer (VSM). The influence of heating rate on the austenite transformation temperatures and the formation of austenite in two stages was measured using dilatometry and analyzed by applying a modified Kissinger method to obtain the activation energy for the formation of austenite from martensite.

\section{EXPERIMENTAL}

\section{A. Material}

Samples from the as-received material of the 13Cr6Ni2Mo SMSS (X2CrNiMoV13-5-2) studied were taken from two batches with minor differences in composition. The as-received material was supplied in the solution-treated and double-tempered condition with a microstructure consisting of martensite, retained austenite, and a very small fraction of carbides, nitrides, and carbonitrides. ${ }^{[5]}$ The composition of the material is given in Table I.

\section{B. Heat Treatments}

An overview of the heat treatments performed in this work is shown in Figure 1. Two different austenitization treatments (heat treatment A) were chosen: a conventional austenitization treatment at low temperature with short-term soak and one at high temperature with long-term soak. The latter provides an increased homogenization of the material. After the austenitization treatment, the samples were either reheated to $1223 \mathrm{~K}\left(950^{\circ} \mathrm{C}\right)$ (heat treatment B) or tempered (heat treatment $\mathrm{C}$ ). The heat treatment steps are described in the following sections.

\section{Austenitization treatments}

The as-received material was austenitized in an air furnace at $1223 \mathrm{~K}\left(950{ }^{\circ} \mathrm{C}\right)$ for 0.5 hour and at $1323 \mathrm{~K}$ $\left(1050{ }^{\circ} \mathrm{C}\right.$ ) for 30.5 hours, for the two treatments, followed by quenching in water (see Figure 1). The microstructure of the material after quenching is martensitic with 2 to 4 vol pct of retained austenite. The term 'austenitization' in this paper is used to refer to these austenitization treatments. The symbols $T_{\mathrm{A}}$ and $t_{\mathrm{A}}$ denote the austenitization temperature and time.

\section{Reheating experiments}

The reheating experiments were carried out in a Bähr $805 \mathrm{~A} / \mathrm{D}$ dilatometer. Samples with a diameter of $5 \mathrm{~mm}$ and length of $10 \mathrm{~mm}$ were cut using an electro-discharge machine (EDM). An S-type thermocouple, spot-welded on the center of the sample surface, was used to control and measure the sample temperature.

The differently austenitized samples were heated to $1223 \mathrm{~K}\left(950{ }^{\circ} \mathrm{C}\right)$ with heating rates between 1 and $100 \mathrm{~K} / \mathrm{min}$, held there for 0.5 hour, and subsequently quenched to room temperature using helium gas (see heat treatment B in Figure 1). Three experiments per heating rate were carried out. In Figure 2, examples of dilatation, $\Delta L / L_{0}$, vs temperature curves are given for an as-received sample, containing about 23 vol pct austenite, heated at $3 \mathrm{~K} / \mathrm{min}$, and a sample austenitized at 1223 $\mathrm{K}\left(950^{\circ} \mathrm{C}\right)$ for 0.5 hour, heated at $1 \mathrm{~K} / \mathrm{min} . \Delta L$ is the change in length and $L_{0}$ the initial length. The austenite formation from martensite is taking place in two stages

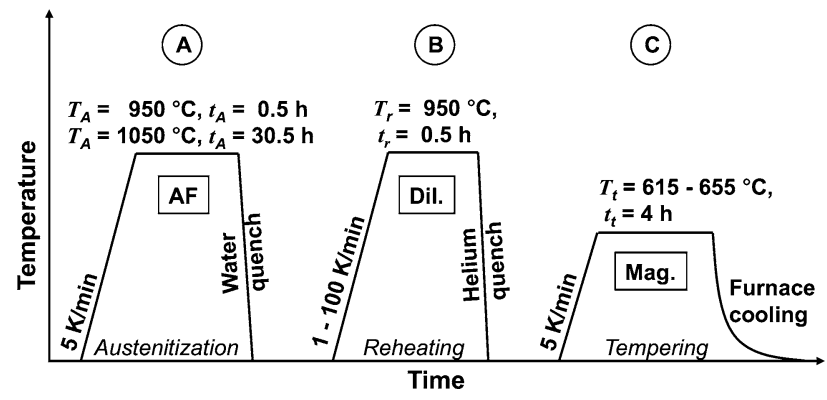

Fig. 1 - Scheme of the applied heat treatment steps A, B, and C. T and $t$ denote temperature and time. Subscripts ' $A$ ' denote austenitization, ' $r$ ' reheating, and ' $t$ ' tempering. 'AF' denotes treatment in air furnace, 'Dil.' in dilatometer, and 'Mag.' in magnetometer.

Table I. Chemical Composition of the 13Cr6Ni2Mo SMSS (in Wt Pet), Balance Fe

\begin{tabular}{lcccccccc}
\hline $\mathrm{C}$ & $\mathrm{Cr}$ & $\mathrm{Ni}$ & $\mathrm{Mo}$ & $\mathrm{Mn}$ & $\mathrm{Si}$ & $\mathrm{V}$ & $\mathrm{Ti}$ & $\mathrm{N}$ \\
\hline 0.02 & 12.27 & 5.62 & 2.01 & 0.42 & 0.21 & 0.18 & 0.01 & 0.016 \\
\hline
\end{tabular}




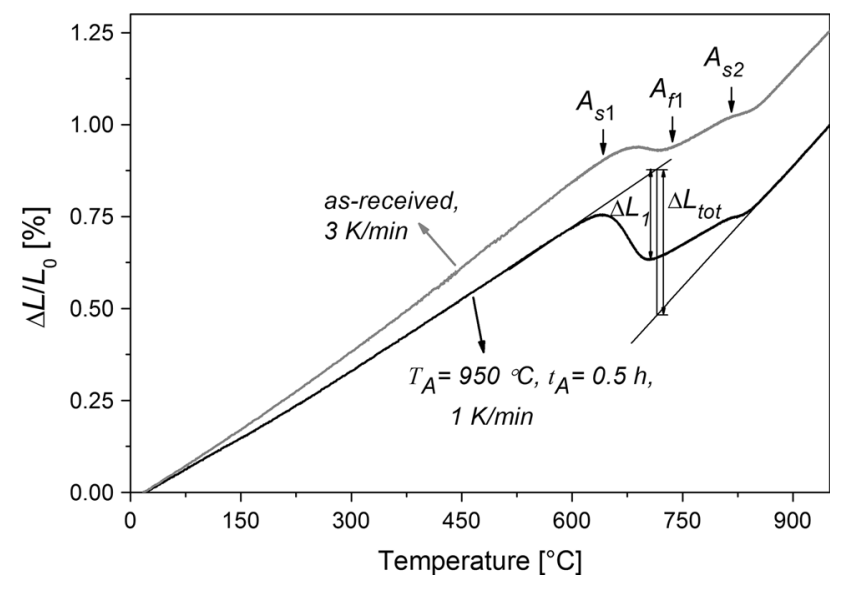

Fig. 2-Dilatation $v s$ temperature of an as-received sample, heated at $3 \mathrm{~K} / \mathrm{min}$, and a sample previously austenitized at $1223 \mathrm{~K}\left(950^{\circ} \mathrm{C}\right)$ for $0.5 \mathrm{~h}$, heated at $1 \mathrm{~K} / \mathrm{min}$. $A_{\mathrm{s} 1}$ and $A_{\mathrm{f} 1}$ denote the start and finish temperatures of the first stage of austenite formation, respectively, and $A_{\mathrm{s} 2}$ the start of the second stage. $\Delta L_{1}$ and $\Delta L_{\mathrm{tot}}$ are measures for the lever-rule.

and the temperatures $A_{\mathrm{s} 1}$ and $A_{\mathrm{f} 1}$ denote the start and finish of the austenite formation in the first stage, respectively. $A_{\mathrm{s} 2}$ denotes the start of the austenite formation in the second stage. A temperature corresponding to the finish of the second stage of martensite-to-austenite transformation was not obtained from the present experiments, as will be described later in Section III-A-2. The transformation temperature range was defined as the temperature range at which 1 and 99 vol pct of the product phase were formed. The precision is $\pm 5{ }^{\circ} \mathrm{C}( \pm 5 \mathrm{~K})$.

The austenite fraction, $f_{\gamma}$, was obtained by the lever-rule ${ }^{[23]}$ from the measured length changes, as shown in Figure 2, by

$$
f_{\gamma}=\frac{\Delta L_{1}}{\Delta L_{\mathrm{tot}}}
$$

where $\Delta L_{1}$ is the difference between the measured length change and the extrapolated length change of martensite; $\Delta L_{\text {tot }}$ is the total length change between the extrapolated austenite and martensite length changes both at a specific temperature. The estimated uncertainty of the austenite fraction obtained by the lever-rule in this work is $\pm 3 \mathrm{vol}$ pct. However, lever-rule analysis relies on the assumption that lattice spacing for martensite and austenite depends on temperature only. The redistribution of alloying elements during heat treatment could increase the uncertainty of the austenite fraction in this study to approximately \pm 6 vol pct.

\section{Tempering treatments}

Magnetic measurements were carried out to analyze the influence of austenitization treatment on the austenite fraction that is retained at room temperature after the tempering treatment (see heat treatment $\mathrm{C}$ in Figure 1).

Tempering treatments of the previously austenitized samples were carried out in a VSM 7307, manufactured by Lake Shore, equipped with a furnace (model 73034). Samples for the tempering experiments in the VSM were cut by EDM to a diameter of $2 \mathrm{~mm}$ and a length of $2 \mathrm{~mm}$. The heating was performed at a nominal rate of $5 \mathrm{~K} / \mathrm{min}$, followed by tempering for 4 hours at temperatures between $888 \mathrm{~K}$ and $928 \mathrm{~K}\left(615^{\circ} \mathrm{C}\right.$ and $\left.655^{\circ} \mathrm{C}\right)$. The cooling was carried out in the VSM furnace. In situ thermo-magnetic analysis of the formation of austenite during tempering treatments has been carried out in a previous study and further details about the experiments can be found in Reference 24 .

Immediately after cooling from tempering, the magnetization of the samples was measured at $1.5 \mathrm{~T}$, a value close to its saturation (see Reference 24). The corresponding austenite fraction, $f_{\gamma}$, was obtained by ${ }^{[25]}$

$$
f_{\gamma}=1-\frac{M_{\text {sat }}(c)}{M_{\text {sat }}(\mathrm{ref})},
$$

where $M_{\text {sat }}(c)$ denotes the measured saturation magnetization of the austenite-containing sample and $M_{\text {sat }}($ ref $)$ the saturation magnetization of a fully martensitic reference sample of the same composition, obtained as described in Reference 24. The saturation magnetization depends only on the phases present in the material and their compositions, but is insensitive to other microstructural features such as texture or defects. ${ }^{[26,27]}$ The estimated uncertainty of the calculated austenite fraction from the measured magnetization at room temperature is $\pm 0.5 \mathrm{vol}$ pct, which includes the uncertainty from the measurement and the reference sample.

\section{Microscopy}

The microstructures of selected tempered samples were analyzed using optical microscopy (OM) and a JEOL JSM 6500 field emission gun scanning electron microscope (FEG-SEM) operated at $15 \mathrm{kV}$. Samples were metallographically prepared with a final polishing step of $1 \mu \mathrm{m}$ diamond paste and subsequently etched. For OM analysis, the SMSS samples were etched for 10 to 120 seconds in Kalling's No. 2 etch $\left(5 \mathrm{~g} \mathrm{CuCl}_{2}, 100\right.$ $\mathrm{ml} \mathrm{HCl}, 100 \mathrm{ml}$ ethanol). ${ }^{[28]}$ For SEM analysis, the SMSS samples were etched for 15 to 30 seconds in a modified Vilella's reagent $(1 \mathrm{~g}$ picric acid, $10 \mathrm{ml} \mathrm{HCl}$, $100 \mathrm{ml}$ ethanol), in which the $\mathrm{HCl}$ addition was increased from $5^{[28]}$ to $10 \mathrm{ml}$ to compensate for the high corrosion resistance of the alloy being studied.

\section{RESULTS}

\section{A. Influence of Previous Austenitization Treatment and the Heating Rate on Austenite Formation Upon Reheating}

1. Reheating to $1223 \mathrm{~K}\left(950^{\circ} \mathrm{C}\right)$

Dilatation curves during reheating between $873 \mathrm{~K}$ and $1223 \mathrm{~K}\left(600^{\circ} \mathrm{C}\right.$ and $\left.950{ }^{\circ} \mathrm{C}\right)$ of the different previously austenitized samples are shown in Figure 3 for all heating rates. For better visualization, the curves are shifted along the $y$-axis. All curves show a distinct first contraction between $923 \mathrm{~K}$ and $1023 \mathrm{~K}\left(650{ }^{\circ} \mathrm{C}\right.$ and 
$750{ }^{\circ} \mathrm{C}$ ), marked by the temperatures $A_{\mathrm{s} 1}$ and $A_{\mathrm{f} 1}$. Another change in length with a smaller expansion coefficient between $1073 \mathrm{~K}$ and $1173 \mathrm{~K}\left(800{ }^{\circ} \mathrm{C}\right.$ and $900{ }^{\circ} \mathrm{C}$ ) is observed in some curves, where the beginning is marked by $A_{\mathrm{s} 2}$. This is attributed to the formation of austenite from martensite in two stages, as will be described later. With increasing heating rate, the second stage becomes less pronounced and is also less pronounced for the samples austenitized at $1323 \mathrm{~K}$ $\left(1050{ }^{\circ} \mathrm{C}\right)$. The separation of the austenite formation in two stages is much more pronounced for the as-received sample, shown in Figure 2, than for the samples which have been given the austenitization treatment. This is seen by the different relative length changes between the two stages.

The influence of heating rate on the transformation temperatures $A_{\mathrm{s} 1}, A_{\mathrm{f} 1}$, and $A_{\mathrm{s} 2}$ is shown in the continuous-heating-transformation (CHT) diagram in Figure 4. The transformation temperatures increase with increasing heating rate, whereas the temperatures for the samples austenitized at $1223 \mathrm{~K}\left(950{ }^{\circ} \mathrm{C}\right)$ for 0.5 hour are lower than for the samples austenitized at $1323 \mathrm{~K}\left(1050{ }^{\circ} \mathrm{C}\right)$ for 30.5 hours. This difference is about $10 \mathrm{~K}\left(10^{\circ} \mathrm{C}\right)$ for the first stage and about $30 \mathrm{~K}$ $\left(30{ }^{\circ} \mathrm{C}\right)$ for the start of the second stage of austenite formation. Since with increasing heating rate the second stage becomes less pronounced, it was not possible to define the start of the second stage clearly for higher heating rates, as can be seen in Figure 4. However, this does not necessarily mean that the second stage of transformation does not take place at high heating rates, but it might start later. The finish of the second stage of austenite formation could not be determined, as will be described in Section III-A-2.

In Figure 5, the change in the transformation temperatures as a function of heating rate is presented. It can be seen that the influence of heating rate is strongest up to $20 \mathrm{~K} / \mathrm{min}$. The transformation temperatures were fitted with

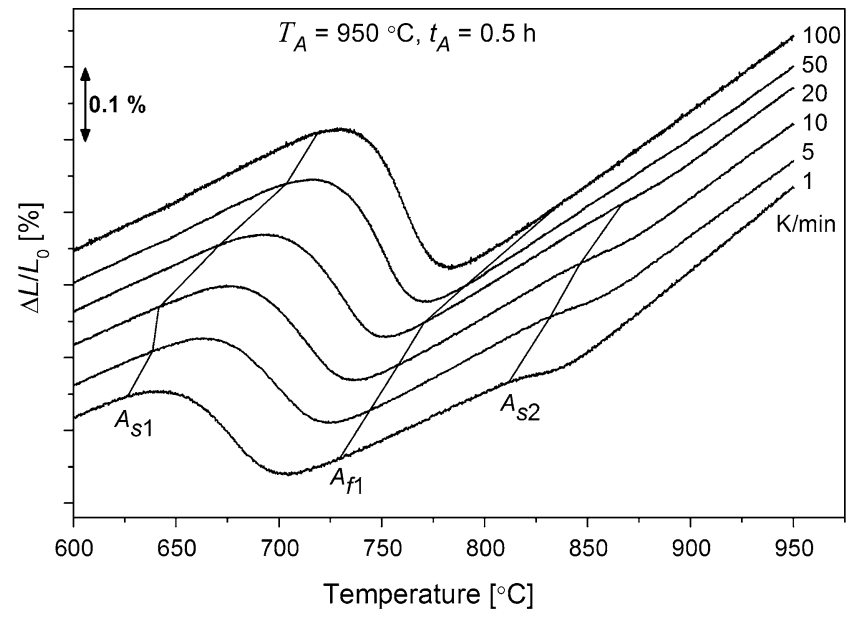

(a)

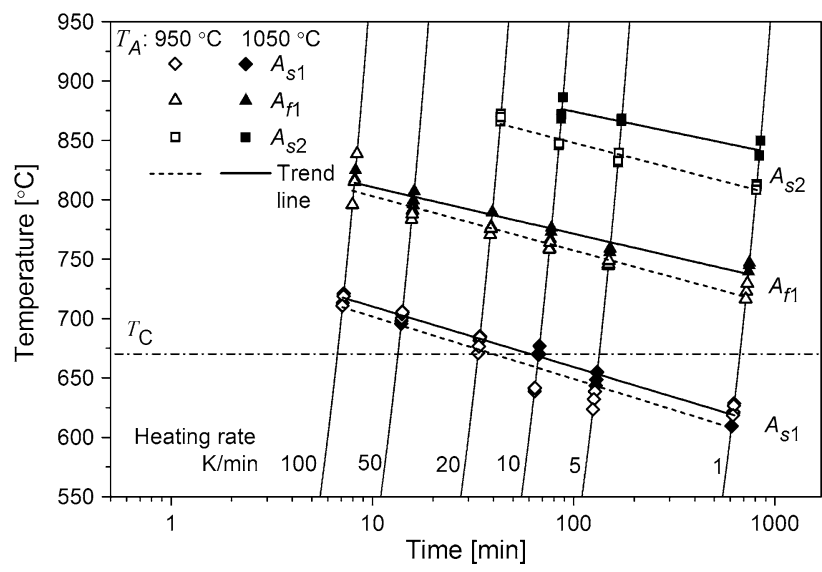

Fig. 4 - Continuous-heating-transformation (CHT) diagram for reheating of the different previously austenitized samples. $T_{\mathrm{C}}$ is the Curie temperature of the bulk material. ${ }^{[14]}$

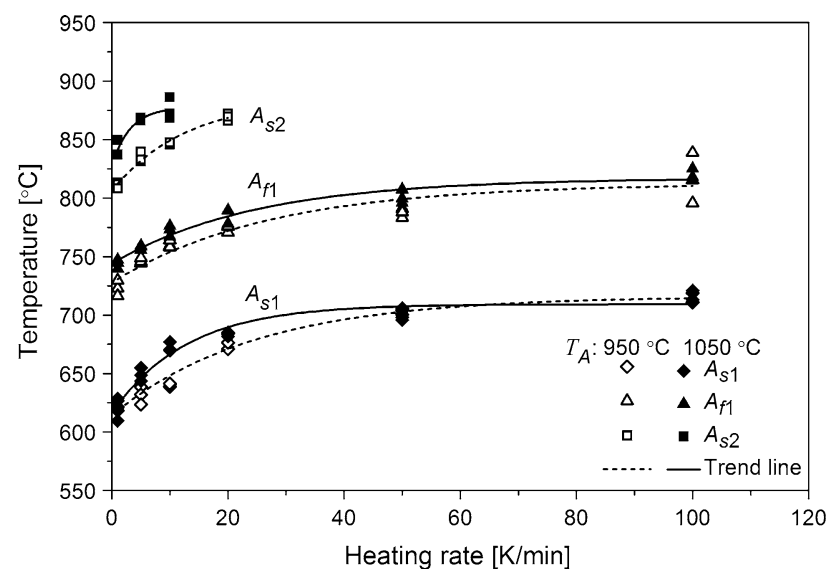

Fig. 5-Variation of $A_{\mathrm{s} 1}, A_{\mathrm{f} 1}$, and $A_{\mathrm{s} 2}$ with heating rate for reheating of the different previously austenitized samples.

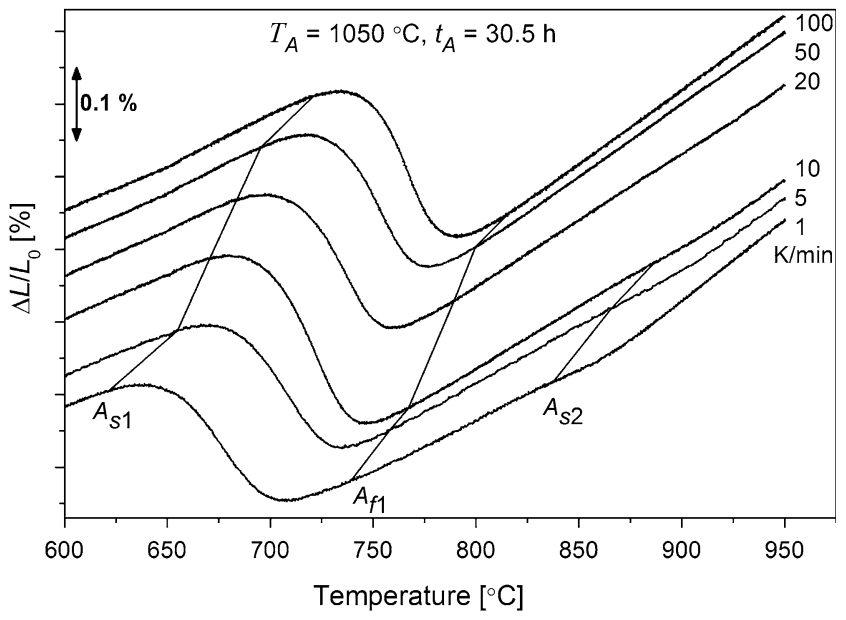

(b)

Fig. 3-Dilatation $v s$ temperature during reheating at different heating rates of samples austenitized at $(a) 1223 \mathrm{~K}\left(950{ }^{\circ} \mathrm{C}\right)$ for $0.5 \mathrm{~h}$ and $(b)$ $1323 \mathrm{~K}\left(1050{ }^{\circ} \mathrm{C}\right)$ for $30.5 \mathrm{~h}$. The curves are shifted on the y-axis by 0.05 pct. 


$$
A_{\mathrm{s}, \mathrm{f}}=A_{0}+b\left[1-\exp \left(-\frac{\phi}{r}\right)\right]
$$

where $A_{\mathrm{s}, \mathrm{f}}$ denotes the start and finish transformation temperatures, respectively, $A_{0}$ the extrapolated transformation temperatures to a zero heating rate, $b$ and $r$ constants, and $\Phi$ the heating rate. The fitting parameters $A_{0}, b$, and $r$ are listed in Table II together with the standard deviations obtained from fitting statistics. $\left(A_{0}+b\right)$ equals the temperatures at infinitely high heating rate. The samples austenitized at $1323 \mathrm{~K}$ $\left(1050{ }^{\circ} \mathrm{C}\right)$ for 30.5 hours show lower $b$ values compared to the samples austenitized at $1223 \mathrm{~K}\left(950{ }^{\circ} \mathrm{C}\right)$ for 0.5 hour. This indicates a more homogeneous distribution of alloying elements in the samples austenitized at $1323 \mathrm{~K}\left(1050{ }^{\circ} \mathrm{C}\right)$ for 30.5 hours.

By Eq. [3], the equilibrium transformation temperatures at zero heating rate are obtained. $A_{0}$ is in the following denoted as $A_{0}^{\mathrm{s} 1}, A_{0}^{\mathrm{fl}}$, and $A_{0}^{\mathrm{s} 2}$, indicating that it belongs to the respective transformation temperatures. This extrapolation helps to compare the experimentally obtained transformation temperatures with equilibrium values. The most important equilibrium transformation temperatures and phase stability ranges, calculated with Thermo-Calc ${ }^{[29]}$ for the composition given in Table I, are listed in Table III. The phases fcc-iron, bcc-iron, $\mathrm{M}_{23} \mathrm{C}_{6}, \mathrm{M}_{6} \mathrm{C}$, liquid and $\chi$-phase were allowed to be present for the calculations. ${ }^{[30]}$ In order to consider all aspects in the discussion, calculations have been also carried out allowing Laves phase to be present. Although Laves and $\chi$-phases were not found for the same material, ${ }^{[5]}$ deviations from the original heat treatment (higher tempering temperature and/or time) could lead to Laves ${ }^{[17]}$ and/or $\chi$-phase ${ }^{[31]}$ formation. ${ }^{[30]}$ Furthermore, although the $\chi$-phase might not appear in practice due to kinetic constraints, partitioning of austenite-stabilizing elements could influence the formation of austenite, since its presence lowers the $A_{\mathrm{e} 3}$ temperature. From Table II and Table III, it can be seen that the $A_{\mathrm{e} 3}$ temperature is within the range of the $A_{0}^{\mathrm{f} 1}$ temperatures. Moreover, the dissolution of $\mathrm{M}_{23} \mathrm{C}_{6}, \mathrm{VN}$, and $\chi$-phase occurs within the range of the second stage of the martensite-to-austenite transformation.

2. Holding at $1223 \mathrm{~K}\left(950^{\circ} \mathrm{C}\right)$

In Figure 6, the length changes during holding at $1223 \mathrm{~K}\left(950^{\circ} \mathrm{C}\right)$ of the different previously austenitized samples are shown for the different heating rates. The curves show that the length is still changing during holding at $1223 \mathrm{~K}\left(950{ }^{\circ} \mathrm{C}\right)$. In general, the change in relative length during holding is greater for higher heating rates. Almost no change was detected for the samples heated at a rate of $1 \mathrm{~K} / \mathrm{min}$. When the samples were heated at a rate of $5 \mathrm{~K} / \mathrm{min}$, the decrease in length saturates after approximately 15 minutes of holding. The samples austenitized at $1223 \mathrm{~K}\left(950{ }^{\circ} \mathrm{C}\right)$ for $0.5 \mathrm{~h}$ show, for heating rates up to $20 \mathrm{~K} / \mathrm{min}$, a larger decrease in relative length compared to the samples austenitized at $1323 \mathrm{~K}\left(1050{ }^{\circ} \mathrm{C}\right)$ for 30.5 hours.

For comparison, the change in relative length during holding at $1223 \mathrm{~K}\left(950{ }^{\circ} \mathrm{C}\right)$ of an as-received sample, heated at a rate of $3 \mathrm{~K} / \mathrm{min}$, is added in Figure 6(a). Its decrease in length is greater than for the sample austenitized at $1223 \mathrm{~K}\left(950{ }^{\circ} \mathrm{C}\right)$ for 0.5 hour and heated at a rate of $1 \mathrm{~K} / \mathrm{min}$, and is similar to the length change of the sample austenitized at $1323 \mathrm{~K}\left(1050{ }^{\circ} \mathrm{C}\right)$ for 30.5 hours and heated at a rate of $5 \mathrm{~K} / \mathrm{min}$.

The decreases in length during holding at $1223 \mathrm{~K}$ $\left(950{ }^{\circ} \mathrm{C}\right)$ indicate that the austenite formation of the second stage is not completed after heating to $1223 \mathrm{~K}$ $\left(950{ }^{\circ} \mathrm{C}\right)$. Therefore, temperatures defining the finish of the second stage of austenite formation could not be determined from the measured dilatation curves in the present study. A similar high value of the austenite finish temperature was recently found by Ravi Kumar et al. ${ }^{[32]}$ by high-temperature X-ray diffraction for an Fe-0.023C-11.3Cr-7.6Ni-1.3Mn-0.62Si (wt pct) steel. There, the martensite-to-austenite formation was found to be complete at $1223 \mathrm{~K}\left(950^{\circ} \mathrm{C}\right)$. Christien et al. ${ }^{[33]}$

Table II. Overview of the Fitting Parameters $A_{0}, b$, and $r$ from the Fit of Transformation Temperatures in Figure 5 Using Eq. [3]

\begin{tabular}{|c|c|c|c|c|c|c|}
\hline & \multicolumn{3}{|c|}{$T_{\mathrm{A}}=1223 \mathrm{~K}\left(950^{\circ} \mathrm{C}\right)$} & \multicolumn{3}{|c|}{$T_{\mathrm{A}}=1323 \mathrm{~K}\left(1050^{\circ} \mathrm{C}\right)$} \\
\hline & $A_{0}\left[\mathrm{~K}\left({ }^{\circ} \mathrm{C}\right)\right]$ & $b\left[\mathrm{~K}\left({ }^{\circ} \mathrm{C}\right)\right]$ & $r(\mathrm{~K} / \mathrm{min})$ & $A_{0}\left[\mathrm{~K}\left({ }^{\circ} \mathrm{C}\right)\right]$ & $b\left[\mathrm{~K}\left({ }^{\circ} \mathrm{C}\right)\right]$ & $r(\mathrm{~K} / \mathrm{min})$ \\
\hline$A_{\mathrm{s} 1}$ & $\begin{array}{c}887 \pm 4 \\
(614 \pm 4)\end{array}$ & $\begin{array}{c}102 \pm 5 \\
(102 \pm 5)\end{array}$ & $25 \pm 3$ & $\begin{array}{c}889 \pm 5 \\
(616 \pm 5)\end{array}$ & $\begin{array}{c}93 \pm 6 \\
(93 \pm 6)\end{array}$ & $13 \pm 2$ \\
\hline$A_{\mathrm{f} 1}$ & $\begin{array}{l}1001 \pm 6 \\
(728 \pm 6)\end{array}$ & $\begin{array}{c}85 \pm 8 \\
(85 \pm 8)\end{array}$ & $27 \pm 8$ & $\begin{array}{l}1017 \pm 3 \\
(744 \pm 3)\end{array}$ & $\begin{array}{c}73 \pm 4 \\
(73 \pm 4)\end{array}$ & $25 \pm 4$ \\
\hline$A_{\mathrm{s} 2}$ & $\begin{array}{c}1079 \pm 3 \\
(806 \pm 3)\end{array}$ & $\begin{array}{c}76 \pm 7 \\
(76 \pm 7)\end{array}$ & $13 \pm 3$ & $\begin{array}{r}1101 \pm 10 \\
(828 \pm 10)\end{array}$ & $\begin{array}{c}50 \pm 8 \\
(50 \pm 8)\end{array}$ & $3 \pm 2$ \\
\hline
\end{tabular}

Table III. Overview of Most Important Equilibrium Transformation Temperatures and Phase Stability Ranges for the Present Study Obtained by Thermo-Calc ${ }^{[29]}$

\begin{tabular}{lcllll}
\hline Laves and $\chi$-phases & $A_{e 3}\left[\mathrm{~K}\left({ }^{\circ} \mathrm{C}\right)\right]$ & $\mathrm{M}_{6} \mathrm{C}\left[\mathrm{K}\left({ }^{\circ} \mathrm{C}\right)\right]$ & $\mathrm{M}_{23} \mathrm{C}_{6}\left[\mathrm{~K}\left({ }^{\circ} \mathrm{C}\right)\right]$ & $\chi\left[\mathrm{K}\left({ }^{\circ} \mathrm{C}\right)\right]$ & $\mathrm{VN}\left[\mathrm{K}\left({ }^{\circ} \mathrm{C}\right)\right]$ \\
\hline Excluded & $1012(739)$ & $<1014(<741)$ & 868 to $1108(595$ to 835$)$ & $\overline{788}$ to $1076(515$ to 803$)$ & $<1206(<933)$ \\
Allowed & $994(721)$ & - & $<1107(<834)$ & $<933)$ \\
\hline
\end{tabular}


also recently observed an $A_{c 3}$ temperature of $1223 \mathrm{~K}$ $\left(950{ }^{\circ} \mathrm{C}\right.$ ) for a $17-4 \mathrm{PH}$ martensitic stainless steel using neutron diffraction measurements, where 5 pct of martensite was still present at $1203 \mathrm{~K}\left(930{ }^{\circ} \mathrm{C}\right)$. Bénéteau et $a l^{[34]}$ reported for a high-nitrogen martensitic stainless steel that 70 pct of the ferrite was transformed between $1118 \mathrm{~K}$ and $1163 \mathrm{~K}\left(845^{\circ} \mathrm{C}\right.$ and $\left.890{ }^{\circ} \mathrm{C}\right)$, whereas in the temperature range between $1163 \mathrm{~K}$ and $1298 \mathrm{~K}\left(890^{\circ} \mathrm{C}\right.$ and $\left.1025^{\circ} \mathrm{C}\right)$ the austenite formation slowly ends.

\section{Calculation of the austenite fraction}

For the analysis of the results, the fractions transformed during holding at $1223 \mathrm{~K}\left(950{ }^{\circ} \mathrm{C}\right)$ need to be calculated first. For this reason, the relative length change during holding at $1223 \mathrm{~K}\left(950{ }^{\circ} \mathrm{C}\right)$ (Figure 6), $\Delta L_{\mathrm{H}} / L_{0}=\left(\Delta L-\Delta L_{\mathrm{H}, \text { ini }}\right) / L_{0}$ with $\Delta L_{\mathrm{H} \text {,ini }}$ the initial value of relative length change during holding, was fitted by an exponential decay equation of the type:

$$
\frac{\Delta L_{H}}{L_{0}}=\frac{\Delta L_{1}}{L_{0}} \exp \left(-\frac{t}{\tau_{1}}\right)+\frac{\Delta L_{2}}{L_{0}} \exp \left(-\frac{t}{\tau_{2}}\right)+\frac{\Delta L_{\text {inf }}}{L_{0}},
$$

where $\Delta L_{1}$ and $\Delta L_{2}$ are the fitting parameters, $\Delta L_{\text {inf }}$ denotes the value of the length change after infinite holding at which the transformation would be complete, $t$ the holding time, and $\tau_{1}$ and $\tau_{2}$ the mean rate parameters.

The austenite fraction during heating, which was obtained by the lever-rule, was corrected for the fraction of austenite at infinite time of holding at $1223 \mathrm{~K}$ $\left(950{ }^{\circ} \mathrm{C}\right)$, when the transformation is assumed to be finished. The austenite fractions, obtained during heating, are shown in Figure 7. The two stages of austenite

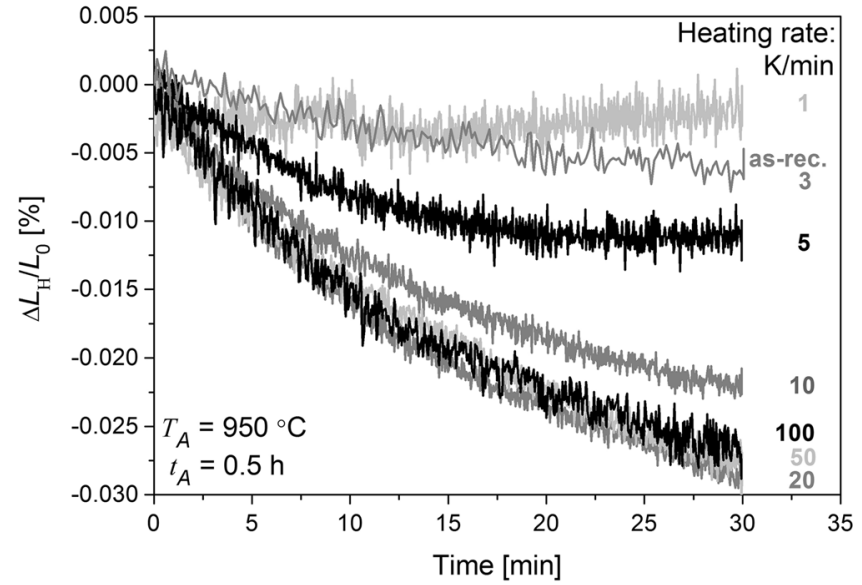

(a)

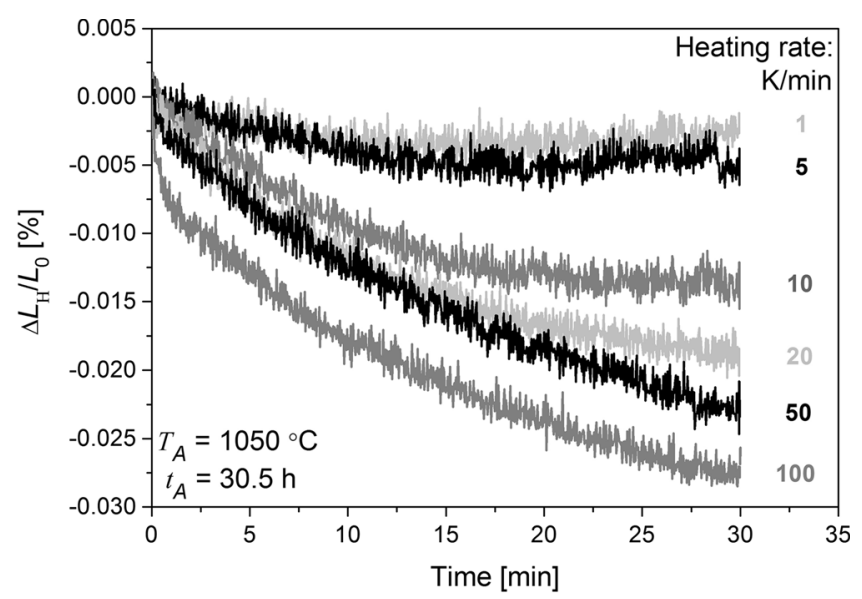

(b)

Fig. 6-Comparison of the relative length changes during holding, $\Delta L_{\mathrm{H}} / L_{0}$, at $1223 \mathrm{~K}\left(950{ }^{\circ} \mathrm{C}\right)$ after heating at different rates for samples previously austenitized at $(a) 1223 \mathrm{~K}\left(950^{\circ} \mathrm{C}\right)$ for $0.5 \mathrm{~h}$ and $(b) 1323 \mathrm{~K}\left(1050^{\circ} \mathrm{C}\right)$ for $30.5 \mathrm{~h}$. The curve of an as-received (as-rec.) sample is also shown in (a).

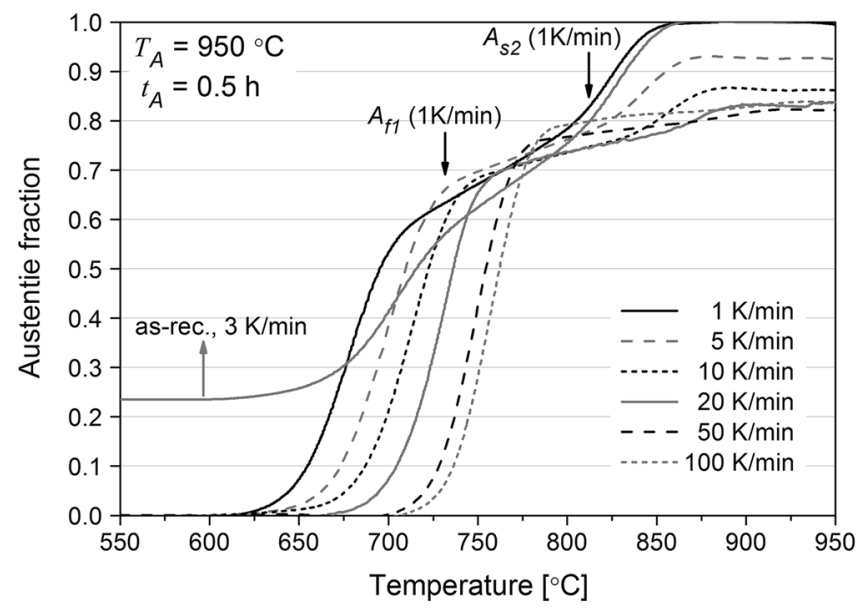

(a)

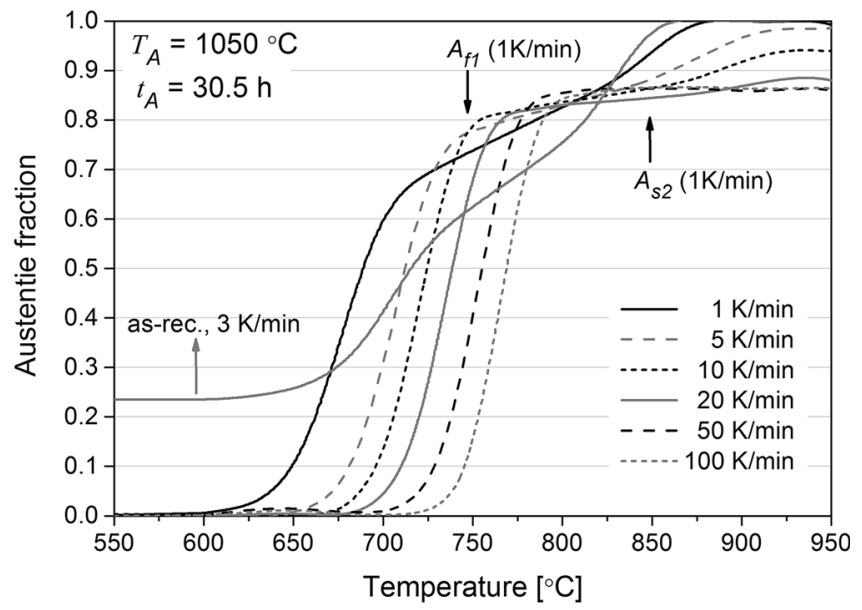

(b)

Fig. 7-Austenite fraction $v$ s temperature for different heating rates with samples previously austenitized at $(a) 1223 \mathrm{~K}\left(950{ }^{\circ} \mathrm{C}\right)$ for $0.5 \mathrm{~h}$ and $(b)$ $1323 \mathrm{~K}\left(1050^{\circ} \mathrm{C}\right)$ for $30.5 \mathrm{~h}$. The austenite fraction of an as-received sample (as-rec.) with an initial austenite fraction of about 0.23 is also presented. 
formation can be clearly seen for the lower heating rates. However, the increase of the austenite fraction between the two stages indicates that austenite also forms in that temperature range, but at a lower rate. The formation rate of austenite between the two stages is decreasing with increasing heating rate. The fraction of austenite formed during the second stage up to $1223 \mathrm{~K}\left(950{ }^{\circ} \mathrm{C}\right)$ is also decreasing with increasing heating rate, whereas the fraction of austenite formed during the first stage appears to be slightly increasing. The samples austenitized at $1223 \mathrm{~K}\left(950^{\circ} \mathrm{C}\right)$ show an approximately 10 pet lower fraction of austenite formed during the first stage than those austenitized at $1323 \mathrm{~K}\left(1050{ }^{\circ} \mathrm{C}\right)$ for the same heating rate. For the second stage the difference is about 5 pct. The austenite fraction of an as-received sample, heated at $3 \mathrm{~K} / \mathrm{min}$, is also included in Figure 7 , showing a lower transformation rate in the first stage and an increased transformation rate in the second stage. This sample shows similar behavior to the sample previously austenitized at $1223 \mathrm{~K}\left(950{ }^{\circ} \mathrm{C}\right)$ and heated with a rate of $1 \mathrm{~K} / \mathrm{min}$.

The austenite fractions, formed during holding at $1223 \mathrm{~K}\left(950{ }^{\circ} \mathrm{C}\right)$ for the different samples, based on the calculations with Eq. [4] and the lever-rule, are shown in Figure 8 . For both previous austenitization treatments, the austenite fraction formed during holding at $1223 \mathrm{~K}$ $\left(950{ }^{\circ} \mathrm{C}\right)$ is increasing with the heating rates up to $10 \mathrm{~K} /$ min. Thereafter, the austenite fraction is almost constant at approximately 13 pct for the samples austenitized at $1223 \mathrm{~K}\left(950^{\circ} \mathrm{C}\right)$ and at approximately 9 pct for the samples austenitized at $1323 \mathrm{~K}\left(1050{ }^{\circ} \mathrm{C}\right)$. The samples heated at a rate higher than $10 \mathrm{~K} / \mathrm{min}$ would continue to form austenite during infinite holding at $1223 \mathrm{~K}$ $\left(950{ }^{\circ} \mathrm{C}\right)$.

\section{Determination of activation energy of austenite formation during heating}

The activation energy governing the transformation during continuous heating can be obtained by a Kissinger-like method, valid also for non-isothermal annealing, which is described by Mittemeijer et al ${ }^{[35-37]}$ The state variable $\beta$ (dimensionless), which determines the fraction transformed, can be obtained for non-isothermal annealing by

$$
\beta=\int_{0}^{t} k d t^{\prime},
$$

where the rate constant $k\left(\mathrm{~s}^{-1}\right)$ is described by an Arrhenius-type equation:

$$
k=k_{0} \exp (-E / R T),
$$

where $t$ denoting the duration of the process considered and $T(\mathrm{~K})$ the temperature, where $T$ and $k$ depend on $t$ for non-isothermal annealing. $E(\mathrm{~J} / \mathrm{mol})$ denotes the effective activation energy of the overall transformation process, $R[8.31441 \mathrm{~J} /(\mathrm{mol} \mathrm{K})]$ the universal gas constant, and $k_{0}\left(\mathrm{~s}^{-1}\right)$ the pre-exponential factor. ${ }^{[35-37]}$

For constant heating rates $\Phi(\mathrm{K} / \mathrm{s}), \beta$ can be obtained by

$$
\beta=\frac{T^{2}}{\phi} \frac{R}{E} k\left\{1-2 \frac{R T_{\mathrm{f}}}{E}+\ldots\right\} \cong \frac{T^{2}}{\phi} \frac{R}{E} k
$$

since $R T_{\mathrm{f}} / E<<1$ for solid-state transformations. ${ }^{[35-37]}$ Taking the temperature for a fixed fraction transformed for various heating rates, $T_{\mathrm{f}}(\mathrm{K})$, into account, ${ }^{[35-37]}$ the activation energy can be obtained by

$$
\ln \left(\alpha \frac{T_{\mathrm{f}}^{2}}{\phi}\right)=\frac{E}{R T_{\mathrm{f}}}+\ln \left(\alpha \frac{E}{R k_{0}}\right)+\ln \beta_{\mathrm{f}},
$$

with $\alpha=1 /(\mathrm{Ks})$, introduced to make the argument of the logarithm dimensionless. $\alpha$ is necessary for consistency. The only alternative solution is to use the exponential equation:

$$
\frac{T_{\mathrm{f}}^{2}}{\phi}=\frac{E \beta_{\mathrm{f}}}{R k_{0}} \exp \left(\frac{E}{R T_{\mathrm{f}}}\right)
$$

Applying the Kissinger-like method requires the following conditions. The original Kissinger method was developed for homogeneous reactions, but was found to be applicable for heterogeneous reactions as well, ${ }^{[36]}$ since $T_{\mathrm{f}}$ depends systematically on the heating rate. ${ }^{[36,38]}$ Heterogeneous transformations are characterized by a maximum transformation rate, where the corresponding temperature $T_{\mathrm{i}}$ occurs at approximately the same transformed fraction $f$. Moreover, in heterogeneous transformations more than one mechanism govern the transformation, e.g., nucleation and growth. If these temperature-dependent sub-steps are thermally activated according to the Arrhenius-type relationship, the assumption of the Arrhenius-type temperature dependence of $k$ holds and the Kissinger-like method can be applied for heterogeneous solid-state transformations. ${ }^{[36,38]}$ Hence, $T_{\mathrm{f}}$ can be replaced by the temperature where the transformation rate is maximum, $T_{\mathrm{i}}$, which corresponds to the point of inflection of the austenite fraction, $f_{\gamma}$, vs $T$ curve. ${ }^{[35,36,38]}$ The activation energy for the austenite formation can then be obtained from the slope of a Kissinger plot of $\ln \left(\alpha T_{\mathrm{i}}{ }^{2} / \Phi\right)$ vs $1 / T_{\mathrm{i}}$ according to Eq. [8]. ${ }^{[35,36,38]}$

The kinetic analysis in the present study was performed on the values of the austenite fraction. It was stated in ${ }^{[37]}$ that the kinetic analysis by non-isothermal dilatometry requires the reference length for the calculation of the degree of transformation. However, since the austenite fraction was obtained directly from the length change by the lever-rule, $T_{\mathrm{i}}$ can also be determined from the austenite fraction as in the present study. The first derivative of the austenite fractions shown in Figure 7 with respect to temperature is plotted in Figure 9 for all the heating rates. For both previous austenitization treatments, two peaks are obtained, related to the two stages of austenite formation. $T_{\mathrm{i}}$ values were obtained by applying a peak position analysis. The peak, and hence the transformation rate, corresponding to the first transformation is higher than the second peak. With increasing heating rate, the peaks are shifted to higher temperatures $T_{\mathrm{i}}$, which correlates with the increase in the transformation temperatures. 
Moreover, the second peak is decreasing with increasing heating rate. The peak positions corresponding to the first and second stages are at higher values of $T_{\mathrm{i}}$ for the samples austenitized at $1323 \mathrm{~K} \quad\left(1050{ }^{\circ} \mathrm{C}\right)$ for 30.5 hours. This corresponds to the differences in the transformation temperatures as shown in Figure 4. Between both stages, the transformation rate is nearly constant and is larger than zero, since the austenite formation did not stop between both stages. However, this rate is very low with a maximum of about $0.0025 \mathrm{~K}^{-1}\left(0.0025^{\circ} \mathrm{C}^{-1}\right)$.

As discussed above, to apply the Kissinger-like method $T_{\mathrm{i}}$ must occur at about the same transformed fraction $f_{\mathrm{i}}$. Therefore, the austenite fractions at $T_{\mathrm{i}}$ are plotted for all heating experiments in Figure 10, including the average values and standard deviations obtained from the austenite fractions at all heating rates at each stage. $f_{\mathrm{i}}$ of the first stage corresponding to a heating rate of $1 \mathrm{~K} / \mathrm{min}$ is noticeably lower than the standard deviation from the average and was therefore excluded from the estimation of the activation energy.
According to Eq. [8], the $\ln \left(\alpha T_{\mathrm{i}}^{2} / \Phi\right)$ vs $1 / T_{\mathrm{i}}$ plots for both previous austenitization treatments and transformation stages are shown in Figure 11. The activation energies obtained from the slope of the linear regressions are given in Table IV. The activation energies calculated were similar for both prior austenitization treatments. The activation energies of the second stage are about $100 \mathrm{~kJ} / \mathrm{mol}$ higher than those of the first stage. Moreover, the activation energies for both stages are almost twice as high as the activation energy of $233 \mathrm{~kJ} / \mathrm{mol}$ for austenite formation during tempering at temperatures between $858 \mathrm{~K}$ and $968 \mathrm{~K}\left(585^{\circ} \mathrm{C}\right.$ and $\left.695^{\circ} \mathrm{C}\right)$ for 4 hours of samples previously austenitized at $1323 \mathrm{~K}$ $\left(1050{ }^{\circ} \mathrm{C}\right)$ for 30.5 hours. ${ }^{[24]}$

\section{B. Influence of Previous Austenitization Treatment on Retained Austenite Fraction After Tempering}

The fractions of austenite, retained after quenching from the austenitization temperature, were $3.0 \pm 0.4 \mathrm{vol}$ pet and $2.2 \pm 0.5 \mathrm{vol}$ pct for the samples

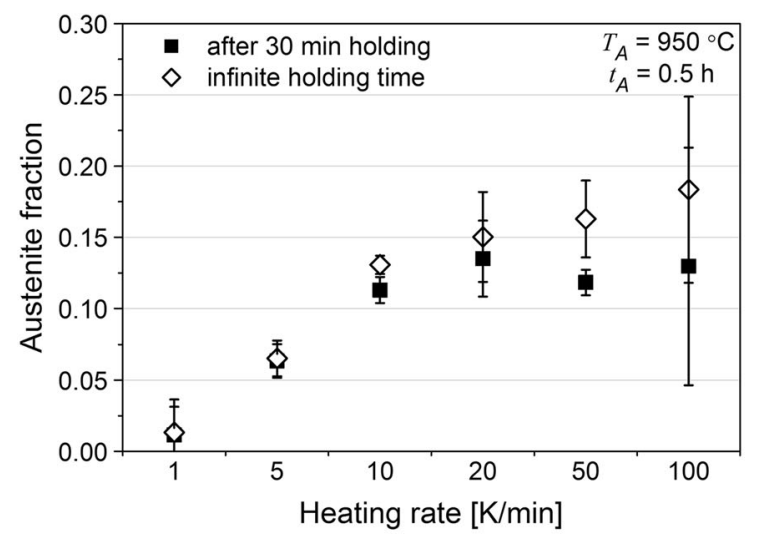

(a)

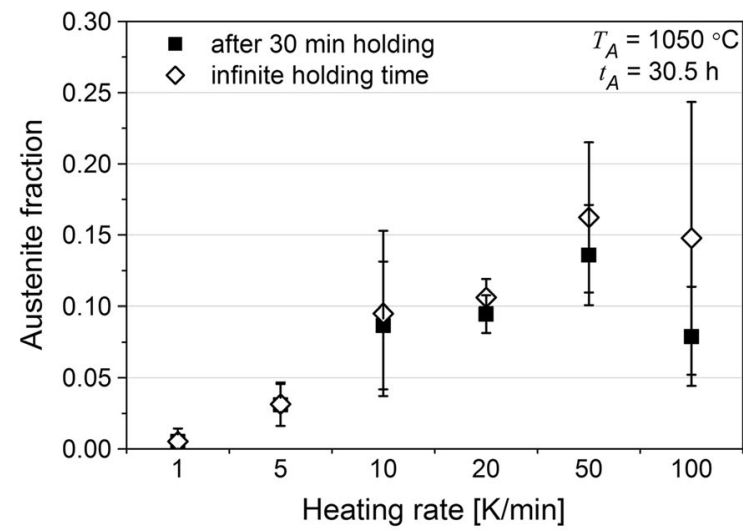

(b)

Fig. 8-Austenite fraction formed during holding at $1223 \mathrm{~K}\left(950^{\circ} \mathrm{C}\right)$ for $30 \mathrm{~min}$ and for infinite holding time, calculated by Eq. [4] and the lever-rule, $v s$ heating rate for the samples previously austenitized at $(a) 1223 \mathrm{~K}\left(950{ }^{\circ} \mathrm{C}\right)$ for $0.5 \mathrm{~h}$ and $(b) 1323 \mathrm{~K}\left(1050{ }^{\circ} \mathrm{C}\right)$ for $30.5 \mathrm{~h}$.

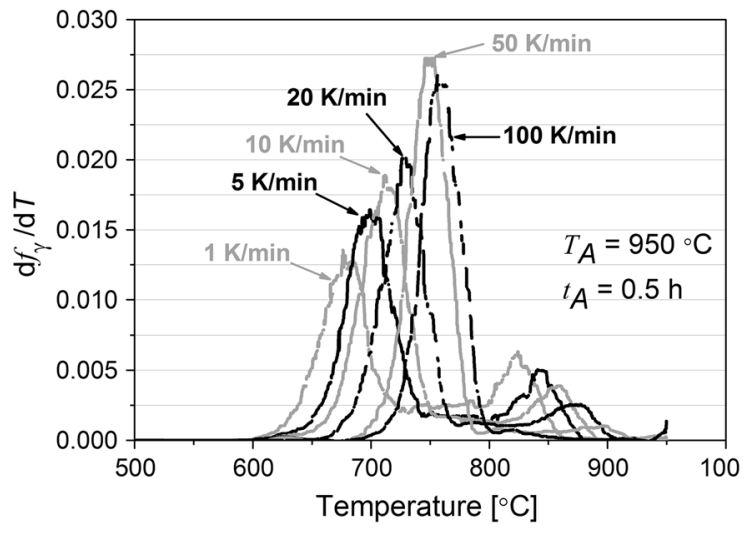

(a)

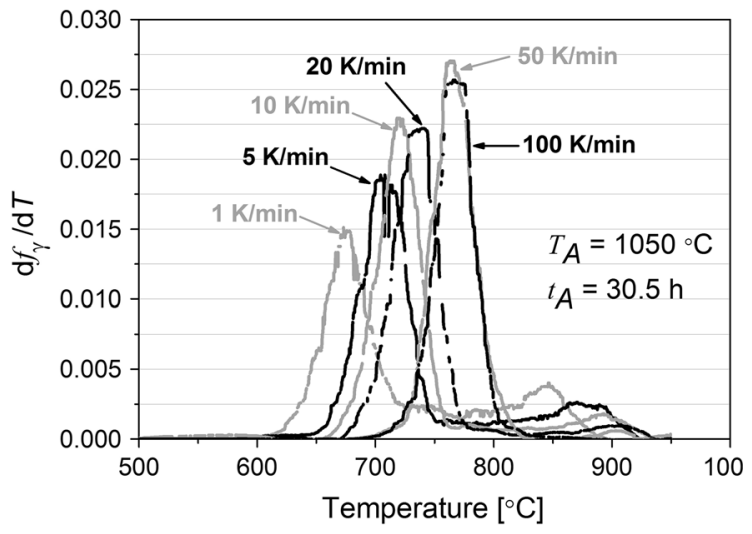

(b)

Fig. 9-Transformation rate $\mathrm{d} f_{\gamma} / \mathrm{d} T$ vs temperature for different heating rates of samples previously austenitized at $(a) 1223 \mathrm{~K}\left(950{ }^{\circ} \mathrm{C}\right)$ for $0.5 \mathrm{~h}$ and $(b) 1323 \mathrm{~K}\left(1050^{\circ} \mathrm{C}\right)$ for $30.5 \mathrm{~h}$. 


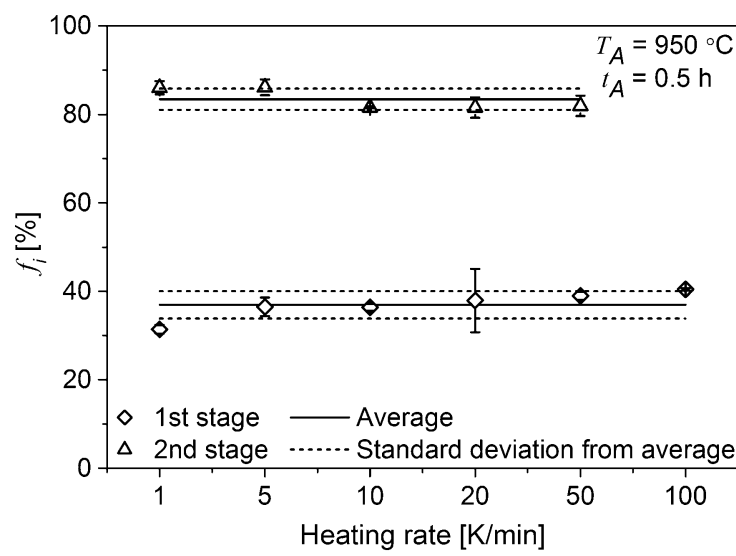

(a)

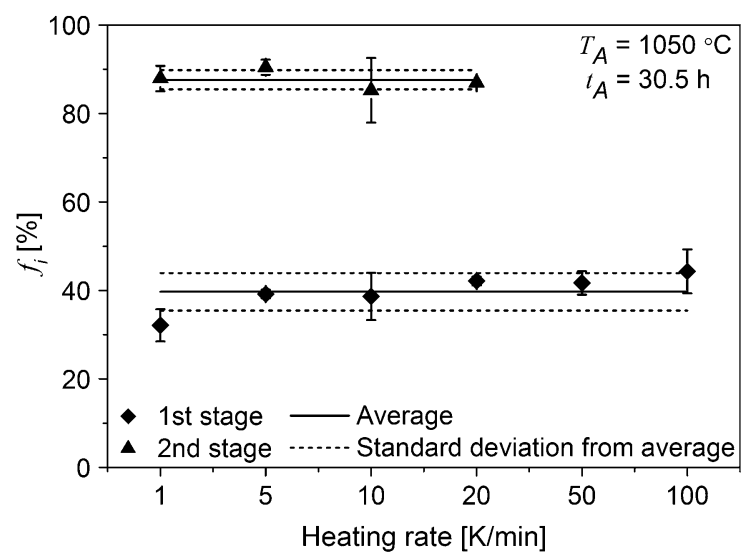

(b)

Fig. $10-$ Overview of the austenite fractions $f_{\mathrm{i}}$ obtained at different peak temperatures $T_{\mathrm{i}}$. The average values correspond to the average of all austenite fractions at each stage, including the standard deviation.

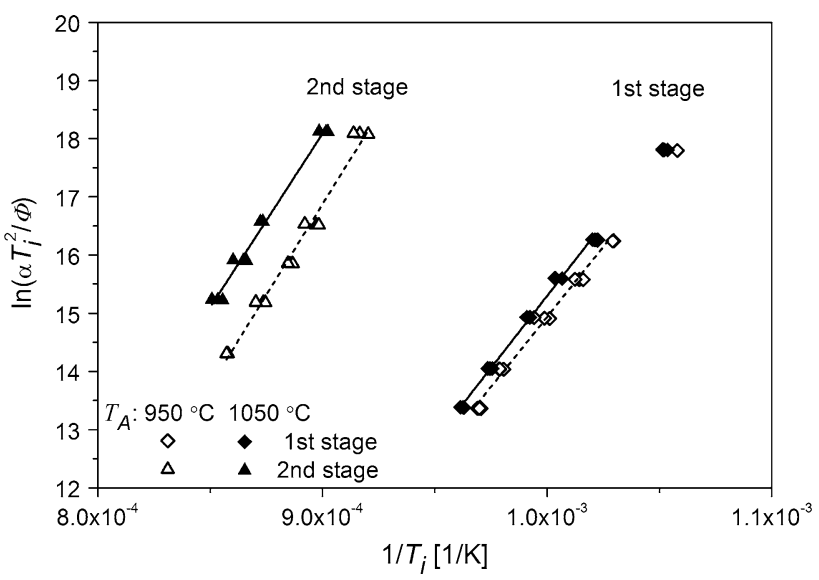

Fig. 11-Kissinger plot of $\ln \left(\alpha \mathrm{Ti}^{2} / \Phi\right)$ vs $1 / T$ i. The values obtained for the first stage for the heating rate of $1 \mathrm{~K} / \mathrm{min}$ were excluded for the estimation of the activation energy.

Table IV. Activation Energies for the Formation of Austenite From Martensite During Heating for the Previous Austenitization Treatments

\begin{tabular}{lccc}
\hline$T_{\mathrm{A}} \mathrm{K}\left({ }^{\circ} \mathrm{C}\right)$ & $t_{\mathrm{A}}(\mathrm{h})$ & 1st Stage $(\mathrm{kJ} / \mathrm{mol})$ & 2nd Stage $(\mathrm{kJ} / \mathrm{mol})$ \\
\hline $1223(950)$ & 0.5 & $400 \pm 14$ & $519 \pm 19$ \\
$1323(1050)$ & 30.5 & $411 \pm 8$ & $497 \pm 17$ \\
\hline
\end{tabular}

previously austenitized at $1223 \mathrm{~K}\left(950^{\circ} \mathrm{C}\right)$ for 0.5 hour and at $1323 \mathrm{~K}\left(1050^{\circ} \mathrm{C}\right)$ for 30.5 hours, respectively. The fractions of retained austenite at room temperature, measured immediately after cooling from tempering between $888 \mathrm{~K}$ and $928 \mathrm{~K}\left(615^{\circ} \mathrm{C}\right.$ to $\left.655^{\circ} \mathrm{C}\right)$ for 4 hours, are shown for both previous austenitization treatments in Figure 12. The data as published in ${ }^{[24]}$ of samples previously austenitized at $1323 \mathrm{~K}\left(1050{ }^{\circ} \mathrm{C}\right)$ for 30.5 hours are shown for comparison. With increasing tempering temperature, the austenite fractions are increasing until a tempering temperature of $913 \mathrm{~K}$ $\left(640{ }^{\circ} \mathrm{C}\right)$. Due to the lower concentration of

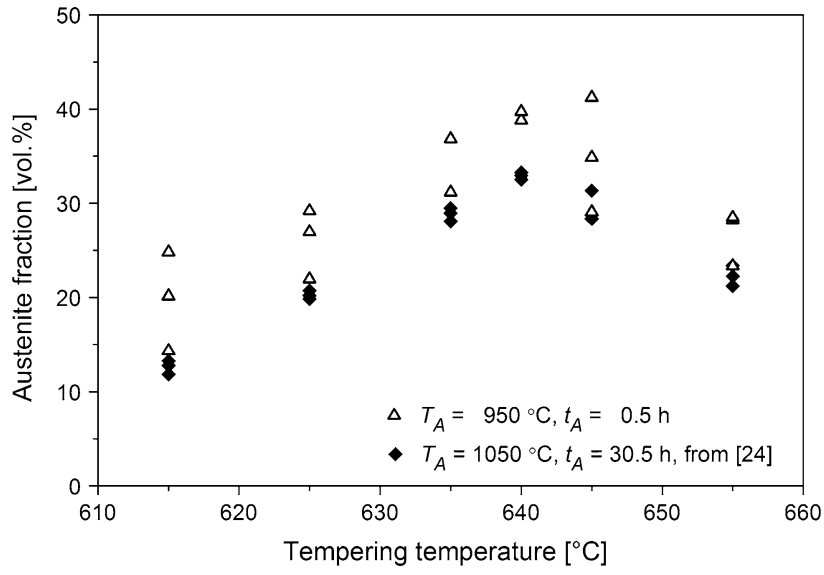

Fig. 12-Evolution of the austenite fraction obtained at room temperature immediately after cooling from tempering for $4 \mathrm{~h}$ for the two series of previously austenitized samples. Estimated uncertainty in austenite fraction: $\pm 0.5 \mathrm{vol}$ pct.

austenite-stabilizing elements in the increased fraction of austenite on tempering, fresh martensite forms during cooling for tempering temperatures exceeding $913 \mathrm{~K}$ $\left(640{ }^{\circ} \mathrm{C}\right)$ leading to a decrease in retained austenite fraction, as discussed in previous work..$^{[24]}$ The samples previously austenitized at $1223 \mathrm{~K}\left(950{ }^{\circ} \mathrm{C}\right)$ for 0.5 hour show a scatter in the austenite fraction of up to 12 vol pct. On the other hand, an austenitization treatment at $1323 \mathrm{~K}\left(1050{ }^{\circ} \mathrm{C}\right)$ for 30.5 hours leads to results showing a greater reproducibility and also a clear peak of the austenite fraction on tempering at $913 \mathrm{~K}$ $\left(640{ }^{\circ} \mathrm{C}\right)$. Moreover, the average austenite fractions of the samples austenitized at $1323 \mathrm{~K}\left(1050^{\circ} \mathrm{C}\right)$ for 30.5 hours are lower than those of the samples austenitized at $1223 \mathrm{~K}\left(950{ }^{\circ} \mathrm{C}\right)$ for 0.5 hour. This difference can be up to 12 vol pct.

\section{Microstructures After Tempering}

Microstructures of samples tempered at $928 \mathrm{~K}$ $\left(655^{\circ} \mathrm{C}\right)$ for 4 hours are shown in Figures 13 and 14 


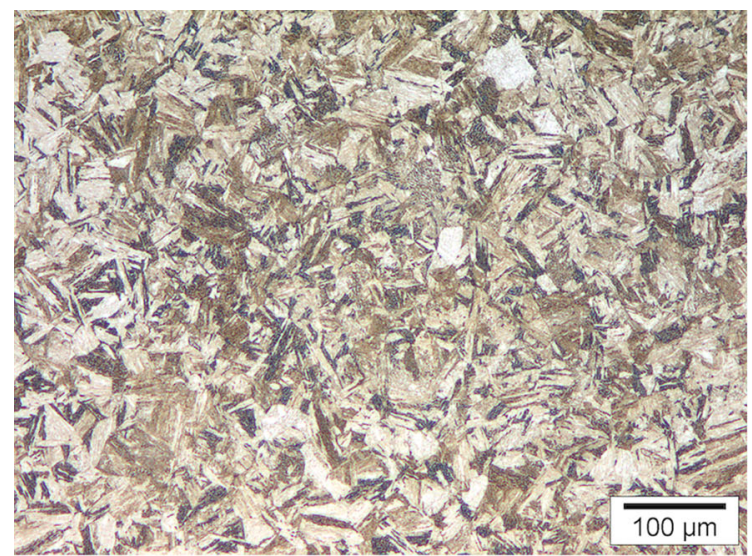

(a)

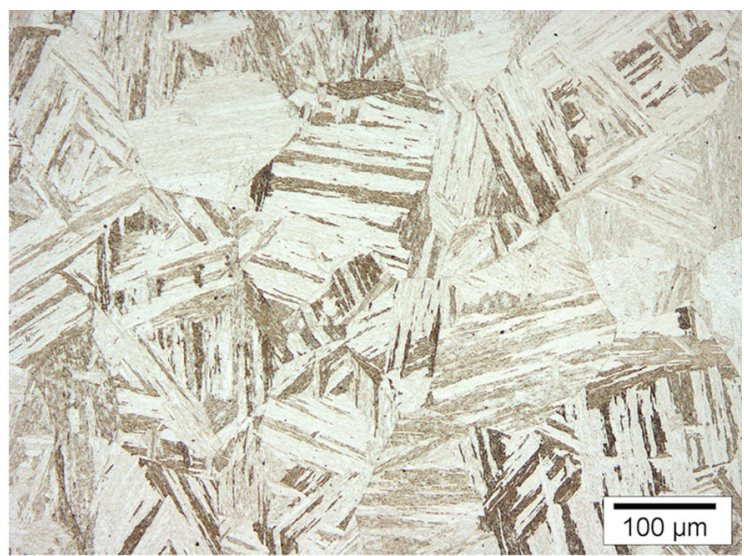

(b)

Fig. 13 - Microstructure of samples tempered at $928 \mathrm{~K}\left(655^{\circ} \mathrm{C}\right)$ for $4 \mathrm{~h}$, previously austenitized at $(a) 1223 \mathrm{~K}\left(950{ }^{\circ} \mathrm{C}\right)$ for $0.5 \mathrm{~h}$ and $(b) 1323 \mathrm{~K}$ $\left(1050^{\circ} \mathrm{C}\right)$ for $30.5 \mathrm{~h}$.

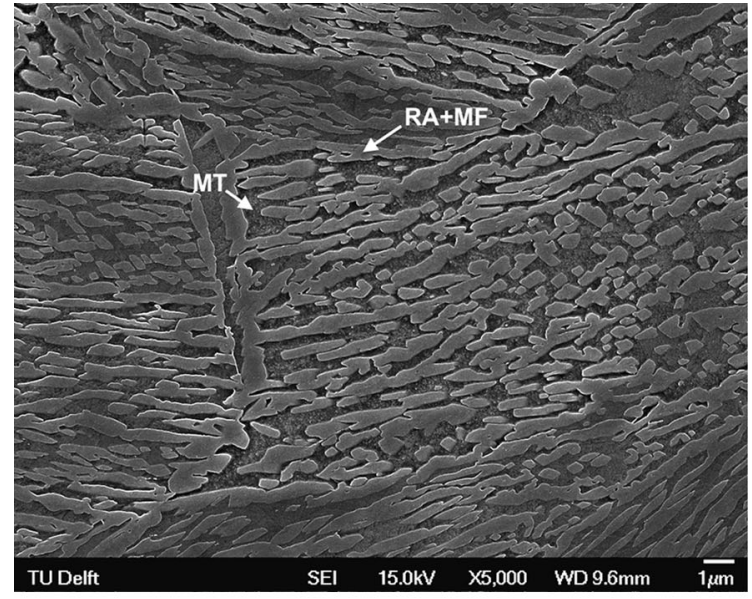

(a)

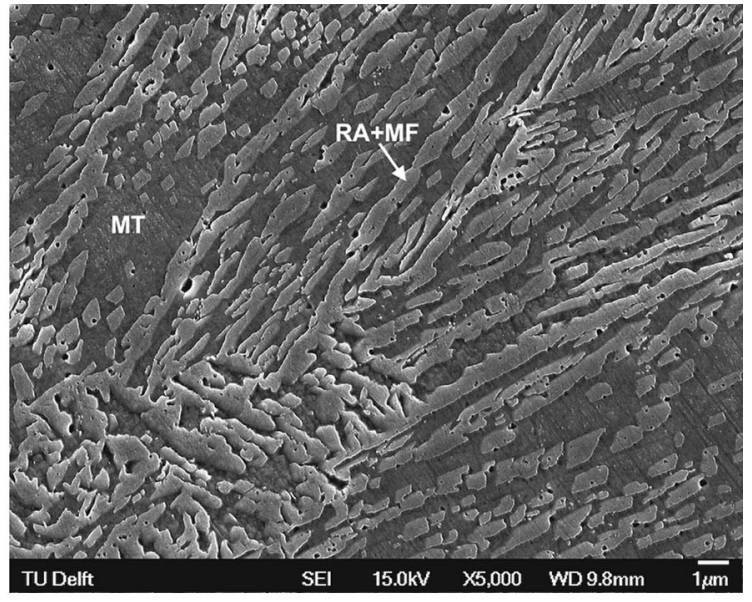

(b)

Fig. 14 - Microstructure of samples tempered at $928 \mathrm{~K}\left(655^{\circ} \mathrm{C}\right)$ for $4 \mathrm{~h}$, previously austenitized at $(a) 1223 \mathrm{~K}\left(950{ }^{\circ} \mathrm{C}\right)$ for $0.5 \mathrm{~h}$ and $(b) 1323 \mathrm{~K}$ $\left(1050^{\circ} \mathrm{C}\right)$ for $30.5 \mathrm{~h}$. Light gray areas indicate retained austenite (RA) + fresh martensite (MF). Dark gray areas indicate tempered martensite (MT).

for both previous austenitization treatments. From the optical micrographs in Figure 13, a greater prior austenite grain size and thus martensite lath size of the sample previously austenitized at $1332 \mathrm{~K}\left(1050{ }^{\circ} \mathrm{C}\right)$ for 30.5 hours can be derived, which in general shows a coarser microstructure than the sample austenitized at $1223 \mathrm{~K}\left(950{ }^{\circ} \mathrm{C}\right)$ for 0.5 hour. Figure 14 shows that the retained austenite (needle-shaped) is finely dispersed in the martensitic matrix. It was reported by Wei ${ }^{[5]}$ that the fresh martensite is attached to the retained austenite, making it difficult to distinguish it with SEM.

\section{DISCUSSION}

\section{A. Austenite Formation in Two Stages}

It was discussed in a previous study ${ }^{[14]}$ that the austenite formation from martensite during continuous heating at $3 \mathrm{~K} / \mathrm{min}$ of an as-received sample occurs in two stages and that martensite is still present at $1107 \mathrm{~K}$ $\left(834^{\circ} \mathrm{C}\right)$. This was found by dilatometry and confirmed by high-temperature X-ray diffraction analysis. From the continuous heating experiments in the present study, it was found that the austenite formation in two stages depends on the heating rate. First, the characteristic transformation temperatures are shifted to higher temperatures with increasing heating rate, which is a well-known effect due to the thermally activated character of the transformation. ${ }^{[15,39-42]}$ Phase transformations can take place by either a diffusional or a shear mechanism. ${ }^{[43,44]}$ Diffusional transformation of martensite to austenite is in general heating rate dependent, whereas a shear transformation is independent of the heating rate. ${ }^{[15,40,45]}$ Thus, the martensite-to-austenite transformation in the present study can be assumed to be diffusional. 
For the austenite formation from martensite, activation energies of about $400 \mathrm{~kJ} / \mathrm{mol}$ for the first stage and about $500 \mathrm{~kJ} / \mathrm{mol}$ for the second stage were obtained (see Table IV). The activation energies for the first stage are around $170 \mathrm{~kJ} / \mathrm{mol}$ higher than the activation energy of $233 \mathrm{~kJ} / \mathrm{mol}$, determined for austenite formation from martensite during isothermal treatment of the 13Cr6Ni2Mo SMSS. ${ }^{[24]}$ A different value of the activation energy implies that a different mechanism is governing the transformation rate. From the tempering experiments presented in our previous work, ${ }^{[24]}$ it is assumed that the growth of austenite in the $13 \mathrm{Cr} 6 \mathrm{Ni2M}$ o SMSS is governed by the diffusion of substitutional austenite-stabilizing elements. The influence of nucleation on the overall activation energy is more complex. Several authors have described the influence of the activation energies of nucleation and growth on the effective activation energy and described numerical solutions for obtaining the individual activation energies from the overall activation energy. ${ }^{[36,46-48]}$ The higher values for the activation energy found in this work are thus believed to be an effective activation energy comprising the energies of both the mechanisms involved, i.e., nucleation and growth. Furthermore, the activation energies obtained for the two stages are similar to those found by Kapoor et al. ${ }^{[40]}$ for the precipitation hardening steel $\mathrm{PH} 13-8 \mathrm{Mo}$, where the martensite-to-austenite transformation occurs through a diffusional mechanism in two stages.

The difference of $100 \mathrm{~kJ} / \mathrm{mol}$ between the two stages could imply a change in the transformation mechanism. A much higher activation energy for the martensite-to-austenite transformation occurring by shear compared to diffusional mechanism was reported for an M350 and a 17-4 PH steel at higher heating rates. ${ }^{[40]}$ Possibly, the increased activation energy for the second stage of martensite-to-austenite transformation in the 13Cr6Ni2Mo SMSS is due to a competing diffusionless mechanism. However, the peak value of $\mathrm{d} f / \mathrm{d} T$ used for determining $T_{\mathrm{i}}$ in the second stage is not as pronounced as in the first stage (see Figure 9), which could influence the precision in $T_{\mathrm{i}}$ determination. Furthermore, since the austenite formation was not finished at $1223 \mathrm{~K}\left(950{ }^{\circ} \mathrm{C}\right)$, this could also influence the position determined for $T_{\mathrm{i}}$ of the second stage and therefore the value of activation energy obtained.

It is assumed that the two-stage formation is promoted by the diffusion of austenite-stabilizing elements such as $\mathrm{Ni}$ and $\mathrm{Mn}$, leaving a reduced concentration in the regions surrounding austenite and hence an increase of the start temperature of austenite formation in those regions. ${ }^{[12]}$ It was observed in other steels that the formation of $\mathrm{Ni}$ precipitates caused Ni-rich and Ni-depleted regions in the matrix, leading to a two-stage formation of austenite. ${ }^{[40,41,45]}$ However, the only precipitates found in the $13 \mathrm{Cr} 6 \mathrm{Ni} 2 \mathrm{Mo}$ SMSS were carbonitrides and $\mathrm{M}_{23} \mathrm{C}_{6}$ and $\mathrm{M}_{6} \mathrm{C}$ carbides, ${ }^{[5]}$ which are rich in $\mathrm{Cr}$ and Mo. Furthermore, the maximum equilibrium fraction of carbides and nitrides in the current steel is below 2 vol pct. ${ }^{[30]}$ This fraction seems to be too low to cause the formation or growth of austenite of about 30 pct during the second stage due to their dissolution, e.g., at a heating rate of $1 \mathrm{~K} / \mathrm{min}$ for the samples austenitized at $1223 \mathrm{~K}\left(950^{\circ} \mathrm{C}\right)$ for 0.5 hour (see Figure 7). However, carbide dissolution during heating could promote the formation of austenite in two stages, where the release of $\mathrm{C}$ lowers the $A_{\mathrm{c} 1}$ temperature. Since martensite was still present in the second stage, ${ }^{[14]}$ the possibility that the second stage is due to carbide and/or nitride dissolution only can be excluded. The $A_{\mathrm{e} 3}$ temperature of the $13 \mathrm{Cr} 6 \mathrm{Ni} 2 \mathrm{Mo}$ SMSS is found to be similar to the $A_{0}^{\mathrm{f} 1}$ temperature of the first stage (see Table II and Table III) and the dissolution of $\chi$-phase, $\mathrm{M}_{23} \mathrm{C}_{6}$, and $\mathrm{VN}$ are in equilibrium within the range of the second stage (see Table III), showing that the second stage of austenite formation might indeed be influenced by carbide/nitride dissolution. $\chi$-phase in the $13 \mathrm{Cr} 6 \mathrm{Ni2Mo}$ SMSS has an approximate equilibrium composition of $\left(\mathrm{Fe}_{31.5}, \mathrm{Ni}_{1.4}\right)$ $\mathrm{Cr}_{12} \mathrm{Mo}_{5.4},{ }^{[30]}$ which would provide little $\mathrm{Ni}$ to cause all the martensite in the second stage to transform. However, in case of $\chi$-phase formation, the release of $\mathrm{Fe}$ and the ferrite stabilizers $\mathrm{Cr}$ and Mo would further increase the formation temperature for austenite, promoting the two-stage formation.

Gooch et $a .^{[8]}$ give an approximation for the $A_{c 1}$ temperature of $13 \% \mathrm{Cr}$ steels with less than 0.05 wt pet $\mathrm{C}$, which is expressed as

$$
\begin{aligned}
A_{\mathrm{c} 1}\left({ }^{\circ} \mathrm{C}\right)= & 850-1500\left(x_{\mathrm{C}}+x_{\mathrm{N}}\right)-50 x_{\mathrm{Ni}}-25 x_{\mathrm{Mn}} \\
& +25 x_{\mathrm{Si}}+25 x_{\mathrm{Mo}}+20\left(x_{\mathrm{Cr}}-10\right),
\end{aligned}
$$

where $x_{\mathrm{i}}$ is the concentration of the alloying elements in wt pet. Accordingly, a concentration of 0.03 wt pet $\mathrm{C}$ in 30 pct of untransformed martensite in the second stage is expected to lower the $A_{\mathrm{c} 1}$ temperature by $45 \mathrm{~K}$ $\left(45^{\circ} \mathrm{C}\right)$. Hence, the formation of the above-mentioned carbides and nitrides would on the one hand lower the concentration of $\mathrm{C}$ and $\mathrm{N}$ in the surrounding matrix, which would increase the $A_{\mathrm{c} 1}$ temperature for the first stage. On the other hand, the concentration of $\mathrm{Cr}$ and Mo would also decrease in the surrounding matrix, which would lower the $A_{\mathrm{c} 1}$ temperature. Owing to a much higher diffusivity of interstitials in iron, the influence of the diffusion of carbide- and nitride-forming substitutional elements is assumed to be localized to the regions around the carbides/nitrides, which offer additional nucleation sites for austenite. Furthermore, the Ni concentration was found to be increased in austenite after tempering of the $13 \mathrm{Cr} 6 \mathrm{Ni} 2 \mathrm{Mo}$ SMSS, while the $\mathrm{Cr}$ concentration was similar in austenite and martensite. ${ }^{[5]}$

The fraction of austenite formed during the first stage is increased with increasing heating rate, while the amount of austenite formed during the second stage decreases. Furthermore, the tendency of the austenite formation to split up into two stages seems to be reduced at higher heating rates and more austenite was formed during holding at the target temperature of $1223 \mathrm{~K}\left(950{ }^{\circ} \mathrm{C}\right)$ (see Figures 6 and 7). These observations again imply the process being diffusional. Heating an as-received sample also showed the austenite formation in two stages, where the extent of the second stage was similar to the samples 
heated at $1 \mathrm{~K} / \mathrm{min}$ (see Figures 2 and 7). This shows that the diffusion of austenite-stabilizing elements to austenite and the carbide/nitride formation influence the two-stage austenite formation. Since the as-received sample was double-tempered, it provides much greater local differences in $\mathrm{Ni}$ and $\mathrm{Mn}$ content together with a higher fraction of carbides compared to the previously austenitized samples.

In summary, the first stage of austenite formation is assumed to be mainly due to partitioning of $\mathrm{Ni}$ and $\mathrm{Mn}$, leaving martensite partially untransformed. Untransformed martensite, due to $\mathrm{Ni}$ - and $\mathrm{Mn}$-depleted regions, might transform due to the dissolution of carbides and nitrides and an increased diffusivity of $\mathrm{Ni}$ and $\mathrm{Mn}$ in the second stage. To support this theory, further research on the distribution of alloying elements during heat treatment is necessary, e.g., using transmission electron microscopy or atom probe tomography. If the reason for the two-stage austenite formation is mainly the partitioning of $\mathrm{Ni}$, it can be assumed that, depending on the local concentration of $\mathrm{Ni}$, a completely austenitic microstructure might not be obtained during austenitization. This can be deduced from the pseudo-binary phase diagram of the $13 \mathrm{Cr} 6 \mathrm{Ni} 2 \mathrm{Mo}$ SMSS, shown in Figure 15, where below an $\mathrm{Ni}$ concentration of $2.8 \mathrm{wt}$ pct, bcc phase is present at all temperatures and $\mathrm{TiN}$ is stable within the temperature range analyzed.

\section{B. Influence of Previous Austenitization Treatment on the Austenite Formation}

The experiments performed showed that an increased previous austenitization temperature and time leads to an increase in the transformation temperatures, especially in the second stage (see Figure 4), and to a lower fraction of austenite formed during holding at $1223 \mathrm{~K}\left(950{ }^{\circ} \mathrm{C}\right.$ ) (see Figure 8). Furthermore, a significant influence of austenitization treatment on the retained austenite fraction, obtained after tempering between $888 \mathrm{~K}$ and $928 \mathrm{~K}$ $\left(615^{\circ} \mathrm{C}\right.$ and $\left.655^{\circ} \mathrm{C}\right)$ for 4 hours, was observed (see

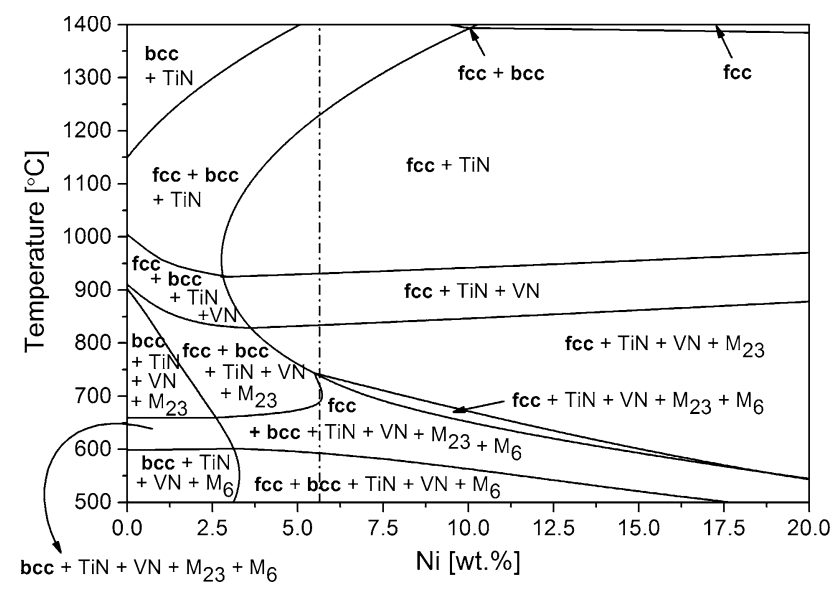

Fig. 15-Pseudo-binary phase diagram from calculations with Thermo-Calc, ${ }^{[29]}$ where Laves and $\Gamma$-phases were excluded. The Ni content of the analyzed $13 \mathrm{Cr} 6 \mathrm{Ni} 2 \mathrm{Mo}$ SMSS is indicated by the dashed-dotted line. TiN $=$ titanium nitride, $\mathrm{VN}=$ vanadium nitride, $\mathrm{M}_{23}=\mathrm{M}_{23} \mathrm{C}_{6}, \mathrm{M}_{6}=\mathrm{M}_{6} \mathrm{C}$.
Figure 12). Smaller values of austenite fraction with smaller variations were obtained when austenitized at $1323 \mathrm{~K}\left(1050{ }^{\circ} \mathrm{C}\right)$ for 30.5 hours. These results suggest that during austenitization at $1323 \mathrm{~K}\left(1050{ }^{\circ} \mathrm{C}\right)$ for 30.5 hours the material is more homogeneous in the distribution of alloying elements than that austenitized at $1223 \mathrm{~K}\left(950^{\circ} \mathrm{C}\right)$ for 0.5 hour. This is also supported by the austenite fraction obtained from the reheating experiments, showing a higher fraction of austenite formed in the first stage. It is worth to mention here again that the as-received material was supplied in the double-tempered condition, hence local differences in alloying elements such as Ni and Mn together with carbides/nitrides were present in the as-received material. The homogenization is thus related to these initial differences.

An increased homogenization would lead to an increased $A_{\mathrm{c} 1}$ temperature. Since partitioning of $\mathrm{Ni}$ and $\mathrm{Mn}$ is mainly rate determining for the austenite formation during tempering and its stabilization during cooling, ${ }^{[24]}$ a locally increased $\mathrm{Ni}$ or $\mathrm{Mn}$ concentration could decrease the total $A_{\mathrm{c} 1}$ temperature as assumed for the previous austenitization at $1223 \mathrm{~K}\left(950{ }^{\circ} \mathrm{C}\right)$ for 0.5 hour. According to Eq. [10], a variation of $25 \mathrm{~K}$ $\left(25^{\circ} \mathrm{C}\right)$ of the $A_{\mathrm{cl}}$ temperature can, for example, be obtained when the $\mathrm{Ni}$ concentration varies by only $0.5 \mathrm{wt}$ pct. The observed variation in the austenite fraction of the tempered samples (Figure 12), austenitized at $1223 \mathrm{~K}\left(950{ }^{\circ} \mathrm{C}\right)$ for 0.5 hour, are significant and suggest local inhomogeneity of austenite-stabilizing elements depending on the previous austenite formation. This is also supported by the higher transformation rate between the two stages for the samples austenitized at $1223 \mathrm{~K}\left(950{ }^{\circ} \mathrm{C}\right)$ for 0.5 hour, since an inhomogeneous $\mathrm{Ni}$ and $\mathrm{Mn}$ distribution provides some areas with a lower temperature for the austenite start formation than the $A_{\mathrm{s} 2}$ temperature. These differences in the transformation rate could also be influenced by the dissolution of carbides and nitrides.

Figure 16 shows the influence of the austenitization temperature on the diffusion distances, $d$, of $\mathrm{Ni}$ and $\mathrm{Mn}$ in fcc-austenite, where the diffusion distance was obtained by $d=\sqrt{D t}$ with $D=D_{0} \exp (-Q /(R T))$. Here, $D$ denotes the diffusion coefficient, $D_{0}$ the

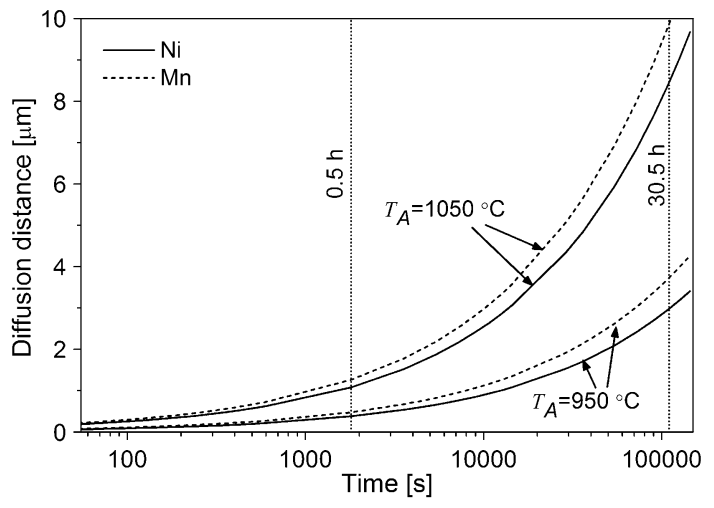

Fig. 16-Diffusion distance of $\mathrm{Ni}$ and $\mathrm{Mn}$ in fcc-iron at $1223 \mathrm{~K}$ and $1323 \mathrm{~K}\left(1050^{\circ} \mathrm{C}\right.$ and $\left.950{ }^{\circ} \mathrm{C}\right)$. Vertical lines indicate austenitization times. 
pre-exponential factor, and $Q$ the activation energy, taken from. ${ }^{[49]}$ It can be seen that after 0.5 hour at 1223 $\mathrm{K}\left(950{ }^{\circ} \mathrm{C}\right) \mathrm{Ni}$ and $\mathrm{Mn}$ diffuse only 0.4 and $0.5 \mu \mathrm{m}$, respectively, compared to 1.1 and $1.3 \mu \mathrm{m}$ at $1323 \mathrm{~K}$ $\left(1050{ }^{\circ} \mathrm{C}\right)$. This is of course dependent on the alloy composition, but indicates that austenitization at $1223 \mathrm{~K}\left(950^{\circ} \mathrm{C}\right)$ for 0.5 hour is not enough to obtain sufficient homogenization of the material. However, further research on the homogenization of the material, e.g., using transmission electron microscopy or atom probe tomography, is necessary to prove this assumption.

Furthermore, the prior austenite grain size can influence austenite formation. It was reported that with increasing austenitization temperature the grain size of the prior austenite increases, ${ }^{[20-22]}$ as can be deduced from the microstructures shown in Figure 13, and hence the size of the lath martensite increases. ${ }^{[20-22]}$ Since the prior austenite grain boundaries and the boundaries of lath martensite act as nucleation sites for the austenite formation in SMSS, ${ }^{[6,9,13,19,20]}$ an increased grain and lath size would provide a lower density of nucleation sites, since the total density of grain boundaries is lower. It can be seen from Figure 14 that the retained austenite grains together with the fresh martensite grains are slightly bigger for the samples previously austenitized at $1323 \mathrm{~K}\left(1050{ }^{\circ} \mathrm{C}\right)$ for 30.5 hours. This could also be responsible for the lower austenite fraction of the samples previously austenitized at $1323 \mathrm{~K}\left(1050{ }^{\circ} \mathrm{C}\right)$ for 30.5 hours, since a lower density of nucleation sites would slow down the formation of austenite by increasing the activation energy for nucleation.

Likewise, austenite that is retained after quenching from austenitization treatment can influence the austenite formation during reheating and tempering such that existing austenite is growing faster, since it does not require nucleation. ${ }^{[50]}$ However, the fraction of austenite retained after quenching from austenitization was about 1 vol pct lower for the samples previously austenitized at $1323 \mathrm{~K}\left(1050{ }^{\circ} \mathrm{C}\right)$ for 30.5 hours and is not considered to have a significant contribution to the much larger difference in austenite fraction obtained after the tempering experiments.

\section{CONCLUSIONS}

The formation of austenite from martensite during continuous heating of a $13 \mathrm{Cr} 6 \mathrm{Ni} 2 \mathrm{Mo}$ SMSS was analyzed using dilatometry and magnetic techniques. The influence of austenitization treatment on austenite formation on reheating and the retained austenite fraction after tempering was analyzed. The main conclusions and findings are as follows:

1. The obtained results suggest a two-stage formation of austenite during heating of the $13 \mathrm{Cr} 6 \mathrm{Ni} 2 \mathrm{Mo}$ SMSS, probably caused by local inhomogeneities of $\mathrm{Ni}$ and $\mathrm{Mn}$ due to their limited diffusion at lower temperatures. The first stage of austenite formation is mainly due to partitioning of $\mathrm{Ni}$ and $\mathrm{Mn}$, leaving martensite partially untransformed. The second stage of austenite transformation is probably governed by an increased diffusivity of $\mathrm{Ni}$ and $\mathrm{Mn}$ at higher temperatures together with the decomposition of carbides and nitrides.

2. The transformation temperatures were shifted to higher temperatures with increasing heating rate, indicating diffusional transformation. An austenitization treatment at $1223 \mathrm{~K}\left(950^{\circ} \mathrm{C}\right)$ for 0.5 hour leads to the start and finish temperatures for the formation of austenite in the first stage being $10 \mathrm{~K}$ $\left(10^{\circ} \mathrm{C}\right)$ lower than the temperatures after austenitization at $1323 \mathrm{~K}\left(1050{ }^{\circ} \mathrm{C}\right)$ for 30.5 hours. The second stage was shifted to higher temperatures by about $30 \mathrm{~K}\left(30^{\circ} \mathrm{C}\right)$.

3. With increasing heating rate, more austenite was formed during the first stage. The second stage of austenite formation became less pronounced and even disappeared at the highest heating rates. It was argued that the transformation is not finished at the target temperature of $1223 \mathrm{~K}\left(950{ }^{\circ} \mathrm{C}\right)$ since, during holding at $1223 \mathrm{~K}\left(950{ }^{\circ} \mathrm{C}\right)$, the relative length is still decreasing, indicating further austenite formation caused by both diffusion of $\mathrm{Ni}$ and $\mathrm{Mn}$ and decomposition of carbides and nitrides.

4. The activation energy for austenite formation from martensite during continuous heating, obtained by a modified Kissinger method, was approximately $400 \mathrm{~kJ} / \mathrm{mol}$ for the first stage and $500 \mathrm{~kJ} / \mathrm{mol}$ for the second stage. These values are believed to be an effective activation energy comprising the energies of both the mechanisms involved, i.e., nucleation and growth.

5. An austenitization treatment at $1323 \mathrm{~K}\left(1050{ }^{\circ} \mathrm{C}\right)$ for 30.5 hours produced a lower retained austenite fraction after different tempering treatments, but with less scatter than the one austenitized at $1223 \mathrm{~K}$ $\left(950{ }^{\circ} \mathrm{C}\right)$ for 0.5 hour. This is assumed to be due to the increased homogenization of the material with respect to the austenite-stabilizing elements, especially $\mathrm{Ni}$, but also $\mathrm{Mn}$, since local inhomogeneity can lead to variations in the austenite fraction at the same tempering temperature. Furthermore, the smaller prior austenite grain size of the samples previously austenitized at $1223 \mathrm{~K}\left(950^{\circ} \mathrm{C}\right)$ for 0.5 hour led to more nucleation sites compared to samples previously austenitized at $1323 \mathrm{~K}\left(1050{ }^{\circ} \mathrm{C}\right)$ for 30.5 hours, which could also influence the fraction of retained austenite.

\section{ACKNOWLEDGMENTS}

This research was carried out under the project number M41.5.10392 in the framework of the Research Program of the Materials innovation institute M2i (www.m2i.nl). The authors wish to thank Cathy Bell and Matthew Green from Tata Steel for their kind support. 


\section{OPEN ACCESS}

This article is distributed under the terms of the Creative Commons Attribution 4.0 International License (http://creativecommons.org/licenses/by/4.0/), which permits unrestricted use, distribution, and reproduction in any medium, provided you give appropriate credit to the original author(s) and the source, provide a link to the Creative Commons license, and indicate if changes were made.

\section{REFERENCES}

1. J.C.M. Farrar: The Alloy Tree: A Guide to Low-Alloy Steels, Stainless Steels and Nickel-Base Alloys, Woodhead Publishing Ltd, Cambridge, 2004, pp. 48-49.

2. J.J. Dufrane: in Supermartensitic Stainless Steel '99, KCI Publishing BV, Brussels, 1999, pp. 19-24.

3. P. Toussaint, J.J. Dufrane: in Supermartensitic Stainless Steel 2002, KCI Publishing BV, Brussels, 2002, pp. 23-28.

4. K. Kondo, M. Ueda, K. Ogawa, H. Amaya, H. Hirata, H. Takabe, Y. Miyazaki: in Supermartensitic Stainless Steel '99, KCI Publishing BV, Brussels, 1999, pp. 11-18.

5. Y. Wei: PhD Thesis, The University of Sheffield, England, 2005.

6. J. Hubackova, V. Cihal, and K. Mazanec: Z. Werkstofftech., 1984 vol. 15, pp. 411-15.

7. P.D. Bilmes, M. Solari, and C.L. Llorente: Mater. Charact., 2001, vol. 46, pp. $285-96$.

8. T.G. Gooch, P. Woollin, A.G. Haynes: in Supermartensitic Stainless Steel '99, KCI Publishing BV, Brussels, 1999, pp. 188-95.

9. Y.Y. Song, X.Y. Li, L.J. Rong, D.H. Ping, F.X. Yin, and Y.Y. Li: Mater. Lett., 2010, vol. 64, pp. 1411-14.

10. Y. Song, X. Li, L. Rong, and Y. Li: Mater. Sci. Eng. A, 2011, vol. 528, pp. 4075-79.

11. X.P. Ma, L.J. Wang, C.M. Liu, and S.V. Subramanian: Mater. Sci. Eng. A, 2011, vol. 528, pp. 6812-18.

12. P. Wang, S. Lu, D. Li, X. Kang, and Y. Li: Acta Metall. Sinica, 2008, vol. 44, pp. 681-85.

13. Y.Y. Song, D.H. Ping, F.X. Yin, X.Y. Li, and Y.Y. Li: Mater. Sci. Eng. A, 2010, vol. 527, pp. 614-18.

14. A. Bojack, L. Zhao, P.F. Morris, and J. Sietsma: Mater. Charact., 2012, vol. 71, pp. 77-86.

15. Y.K. Lee, H.C. Shin, D.S. Leem, J.Y. Choi, W. Jin, and C.S. Choi: Mater. Sci. Technol., 2003, vol. 19, pp. 393-98.

16. C. Gesnouin, A. Hazarabedian, P. Bruzzoni, J. Ovejero-García, P. Bilmes, and C. Llorente: Corros. Sci., 2004, vol. 46, pp. 1633-47.

17. G. Rožnovská, V. Vodárek, A. Korčák, M. Tvrdý: Sborník vědeckých praci Vysoké skoly báňské - Technické univerzity Ostrava, 2005, no. 1, pp. 225-31.

18. C.A.D. Rodrigues, P.L.D. Lorenzo, A. Sokolowski, C.A. Barbosa, and J.M.D.A. Rollo: Mater. Sci. Eng. A, 2007, vol. 460, pp. 149-52.

19. X.P. Ma, L.J. Wang, C.M. Liu, and S.V. Subramanian: Mater. Sci. Eng. A, 2012, vol. 539, pp. 271-79.

20. Y.R. Liu, D. Ye, Q.L. Yong, J. Su, K.Y. Zhao, and W. Jiang: J. Iron Steel Res. Int., 2011, vol. 18 (11), p. 60-6.

21. X. Liu, K. Zhao, Y. Zhou, D. Ye, W. Jiang, Q. Yong, and J. Su: Adv. Mater. Res., 2012, vols. 393-395, pp. 440-43.
22. Y. Zhou, K. Zhao, X. Liu, D. Ye, W. Jiang, Q. Yong, and J. Su: Adv. Mater. Res., 2012, vols. 399-401, pp. 211-15.

23. T.A. Kop, J. Sietsma, and S. van der Zwaag: J. Mater. Sci., 2001, vol. 36 , pp. 519-26.

24. A. Bojack, L. Zhao, P.F. Morris, and J. Sietsma: Metall. Mater. Trans. A, 2014, vol. 45A, pp. 5956-67.

25. L. Zhao, N.H. van Dijk, E. Brück, J. Sietsma, and S. van der Zwaag: Mater. Sci. Eng. A, 2001, vol. 313, pp. 145-52.

26. D.C. Jiles: Acta Mater., 2003, vol. 51, pp. 5907-39.

27. P.E. Merinov and A.G. Mazepa: Ind. Lab. (Diagn. Mater.), 1997, vol. 63 (3), pp. 149-53.

28. G.F. Vander Voort: Metallography, Principles and Practice, McGraw-Hill, Inc, New York, 1984, p. 647.

29. Thermo-Calc Software package, Version S, Database TCFEv6.2, Stockholm, Sweden, 2011.

30. A. Bojack, L. Zhao, and J. Sietsma: Solid State Phenom., 2011, vols. 172-174, pp. 899-904.

31. W. Xu, D. San Martin, P.E.J. del Rivera Diaz Castillo, and S. van der Zwaag: Adv. Mater. Res., 2007, vols. 15-17, pp. 531-36.

32. B. Ravi Kumar, S. Sharma, P. Munda, and R.K. Minz: Mater. Des., 2013, vol. 50, pp. 392-98.

33. F. Christien, M.T.F. Telling, and K.S. Knight: Mater. Charact., 2013, vol. 82, pp. 50-57.

34. A. Bénéteau, P. Weisbecker, G. Geandier, E. Aeby-Gautier, and B. Appolaire: Mater. Sci. Eng. A, 2005, vol. 393, pp. 63-70.

35. E.J. Mittemeijer, L. Cheng, P.J. van der Schaaf, C.M. Brakman, and B.M. Korevaar: Metall. Trans. A, 1988, vol. 19A, pp. 925-32.

36. E.J. Mittemeijer: J. Mater. Sci., 1992, vol. 27, pp. 3977-87.

37. E.J. Mittemeijer, A. van Gent, and P.J. van der Schaaf: Metall. Trans. A, 1986, vol. 17A, pp. 1441-45.

38. W. Baumann, A. Leineweber, and E. Mittemeijer: J. Mater. Sci., 2010, vol. 45, pp. 6075-82.

39. C. Garcia, L.F. Alvarez, and M. Carsi: Weld. Int., 1992, vol. 6, pp. 612-21.

40. R. Kapoor and I.S. Batra: Mater. Sci. Eng. A, 2004, vol. 371, pp. 324-34.

41. A. Goldberg and D.G. O'Connor: Nature, 1967, vol. 213, pp. 170-71.

42. Y.Y. Meshkov and E.V. Pereloma: in Phase Transformations in Steels, E. Pereloma and D.V. Edmonds, eds., Woodhead Publishing, Oxford, 2012, pp. 581-618.

43. R.W.K. Honeycombe and H.K.D.H. Bhadeshia: Steels: Microstructure and Properties, 3rd ed., Elsevier Ltd, Amsterdam, 2006, pp. 7-8.

44. R.D. Doherty: in Physical Metallurgy, R.W. Cahn and P. Haasen, eds., Elsevier Science B.V., Amsterdam, 1996, 2nd ed., vol. 2, pp. $1363-505$.

45. R. Kapoor, L. Kumar, and I.S. Batra: Mater. Sci. Eng. A, 2003, vol. 352 , pp. $318-24$.

46. F. Liu, F. Sommer, C. Bos, and E.J. Mittemeijer: Int. Mater. Rev., 2007, vol. 52, pp. 193-212.

47. Y.H. Jiang, F. Liu, and S.J. Song: Acta Mater., 2012, vol. 60, pp. 3815-29.

48. F. Liu, S.J. Song, F. Sommer, and E.J. Mittemeijer: Acta Mater., 2009, vol. 57, pp. 6176-90.

49. Smithells Metals Reference Book, W.F. Gale, T.C. Totemeier (Eds.), 8 ed., Elsevier Butterworth-Heinemann, Amsterdam, 2004

50. M. De Sanctis, G. Lovicu, R. Valentini, A. Dimatteo, R. Ishak, U. Migliaccio, R. Montanari, and E. Pietrangeli: Metall. Mater. Trans. A, 2015, vol. 46A, pp. 1878-87. 